Article

\title{
Foraminifer and Ostracod Occurrence in a Cool-Water Carbonate Factory of the Cape Adare (Ross Sea, Antarctica): A Key Lecture for the Climatic and Oceanographic Variations in the Last 30,000 Years
}

\author{
Romana Melis *(1) and Gianguido Salvi \\ Department of Mathematics and Geosciences, University of Trieste, via E. Weiss 2, 34127 Trieste, Italy; \\ gsalvi@units.it \\ * Correspondence: melis@units.it
}

Received: 16 September 2020; Accepted: 13 October 2020; Published: 15 October 2020

\begin{abstract}
Foraminifers and ostracods were studied in a gravity-core recovered near Cape Adare (Ross Sea, Antarctica) with the aim of identifying the climatic and oceanographic variations during the last $30 \mathrm{ka}$. The sedimentary sequence represents conditions of a cool-water carbonate factory, which evidences that during the Marine Isotope Stage 2 (MIS2) the area was ice-free and very productive. The overall preservation of delicate skeletal remains such as bryozoans and molluscs indicated moderate bottom currents. This carbonate factory was interrupted by some terrigenous levels, representing conditions of instability/retreat of the ice shelves southward. The younger levels were referred to the meltwater pulse (MWP)-1A and 1B events. The Holocene sequence comprised more terrigenous sediments, reflecting high bottom-currents similar to the present-day conditions. Very abundant and well preserved foraminifers and ostracods, representative of shelf-upper slope paleoenvironments, were recovered. Epistominella exigua, among the foraminifers, suggested the influence of the Circumpolar Deep Water during some periods of the late Quaternary. Heavy-test taxa, such as Cibicides refulgens, indicated strengthening bottom hydrodynamics. As for the ostracods, peaks in the presence of Australicythere devexa, Bairdoppilata simplex and Pseudocythere aff. caudata together with significant values of Polycope spp. allowed us to identify environments rich in nutrients with the influence of cold and deep water upwelling phenomena.
\end{abstract}

Keywords: polar carbonate; biofacies; micropaleontology; glacial dynamic; MWP events; ACR

\section{Introduction}

Scientific interest in polar biogenic carbonates has increased over time as they are very important paleoecological proxies in the study of high latitude settings where abiogenic glacial sediments often prevail. Biogenic calcareous sediments are relatively rare in the Antarctic shelves, since the particular conditions of these polar environments do not generally favour the carbonate "factory". More typically, low temperatures and highly corrosive water masses, generally force the calcite compensation depth (CCD) at approximately 350-1000 $\mathrm{m}$ on the Antarctic shelves [1-3]. In addition, large amounts of siliciclastic sediments related to glacier activities limit the biogenic carbonate production and accumulation. Due to these conditions, biogenic carbonate deposits on the Antarctic shelves are very localised in space and in time [2,4-11].

Studies in the Ross Sea area show that several metres of thick carbonate-rich sequences occur on the north-western banks (Mawson and Pennell), outer continental shelf (northern Drygalski Trough), and upper slope [5,8-10,12]. These gravel- to sand-sized biogenic sediments mainly consist of bryozoan, stylasterine hydrocoral, mollusc, barnacle, foraminifer, ostracod and echinoid tests, skeletal parts or 
particles. In particular, all of the major producers (i.e., bryozoans and stylasterine hydrocorals) of these carbonate sequences require hard substrate to live. They are variably interbedded with muddy intervals, containing calcareous and siliceous microfossils.

This carbonate factory has mainly been related to the maximum expansion of the ice shelves in the Ross Sea, from MIS3 up to the late Pleistocene (Last Glacial Maximum) [5,10], when the glacial expansion limited the siliciclastic influx to the outer shelf. During this time interval, the East Antarctic Ice Shelf (EAIS) was grounded in the proximity of Coulman Island, leaving the northern part of the shelf partially open toward the upper slope $[13,14]$. A hiatus from ca. 22.7 and 3.6 ka has been related to the ice shelf decay and retreat, when the increased terrigenous influx due to the meltwater outflow and iceberg calving affected productivity and the carbonate factory [10].

During the development of the carbonate factory, the accumulation rate may still have been elevated [15], but during the unfavourable conditions for carbonate production, the skeletal debris undergoes significant alteration and remobilisation. Furthermore, reworking phenomena due to gravity flows and iceberg transits together with strong bottom currents could alter these deposits. Thus, an initial autochthonous biogenic concentration could be modified by episodes of physical remoulding, yielding largely parautochthonous/allochthonous fossil assemblages.

Taviani et al. [5] distinguished four distinct facies based on biota composition (mainly barnacles, bryozoans and foraminifers) in the north-western Ross Sea continental shelf. Sedimentological and biological data indicate the common influence of bottom-current activity in several of the investigated areas. Brambati et al., [8] describe a four-metres-thick carbonate/siliciclastic sequence found close to the Cape Adare area that mainly consists of bryozoan and foraminifer remains. Carbonate-rich facies in the Mawson and Pennell Banks surrounding Joides Basin may be the function of several processes, such as undergoing remobilisation due to gravity flow processes, iceberg disturbance on the sea-floor, and/or strong bottom currents, as evidenced in [12]. Melis et al. [9] showed that the biogenic carbonate accumulation increases toward the shelf-break area north of the Drygalski Trough where bryozoan and stylasterine assemblages, accumulated by means of several mass transport events, are interbedded within open marine muddy sediments. Studying 15 piston cores from the northwestern Ross Sea shelf, the authors of [10] identify six facies associations, highlighting the carbonate components in which barnacles, bryozoans, stylasterines and foraminifers are the main carbonate producers. The facies distribution has been used to determine ice shelf fluctuations. Other middle Pleistocene polar carbonates were found in drill hole CPR-1 at Cape Roberts (McMurdo Sound, south Ross Sea) $[7,16]$. Within these carbonate sediments, subsequent autochthonous marine assemblages document the oscillation of the ice-shelf front while reworked Pliocene foraminifers testify to the influence of transport processes.

Microfossils such as foraminifers and ostracods are always recovered in these facies but are not often thoroughly studied. They are potentially very sensitive to post-mortem transport due to their relatively small size, thus taphonomic studies on their remains can also be used to identify different depositional processes. Foraminiferal assemblages are largely autochthonous in deep shelf settings because they accumulate below the storm wave base [17]. In contrast, in high latitude areas, glacial processes are known for test transport, leading to the accumulation of allochthonous fossil assemblages in deep shelf settings [16]. However, even in high dynamic environments such as those located near grounding lines and related grounding zone wedges (GZWs), microfossils can be considered autochthonous, provided they meet certain preservation criteria $[18,19]$. Reworked and transported foraminifers are, in fact, recognised when their tests appear damaged, with different coloration, and/or with sediment filling [20].

We present the study of these microorganisms (foraminifers and ostracods) in core ANTA91-9, located near Cape Adare, on the outer continental Ross Sea shelf. Cape Adare area is characterised by a narrow shelf, which deepens rapidly towards the abyssal plain of the Adare Basin. The shelf break near Cape Adare is a complex region with several advection and mixing processes occurring concurrently. In this area, salty, dense and cold High Salinity Shelf Water (HSSW), flowing northwards from Victoria 
Land, mixes with cold, fresh Antarctic Surface Water (ASW) and warm, salty Circumpolar Deep Water (CDW) at the Antarctic Slope Front to form Antarctic Bottom Water that sinks into the deeper parts of the abyssal plain [21]. This area is currently characterized by moderate to strong currents caused not only by the overflow of the HSSW across the Drygalski Trough sill down the continental slope, but also by strong tidal currents, which here can exceed $0.8 \mathrm{~m} / \mathrm{s}$, compared with $\sim 0.4-0.6 \mathrm{~m} / \mathrm{s}$ for the mean speed of the dense outflow of the HSSW [22-25].

The aim of this work is to verify the potential of foraminifers and ostracods to aid in the study of the paleoenvironmental and climatic variations during the late Quaternary, with the support of sedimentological and geochemical data. These microorganisms have not been thoroughly studied in this area until now. The integrated use of these two taxonomic groups is intended to determine whether they respond unequivocally to the same climatic forcing events. We intend to use multivariate statistics to identify Foraminiferal and Ostracod Assemblages (FAs and OAs) useful for the paleoenvironmental reconstructions.

\section{Materials and Methods}

The gravity core ANTA91-9 (coord. $71^{\circ} 30.77^{\prime}$ S, 171 ${ }^{\circ} 54.22^{\prime}$ E; water depth 573 m, core length 496 $\mathrm{cm}$ ) was collected during the 1991 austral summer cruise of the "Progetto Nazionale di Ricerche in Antartide" (Figure 1).

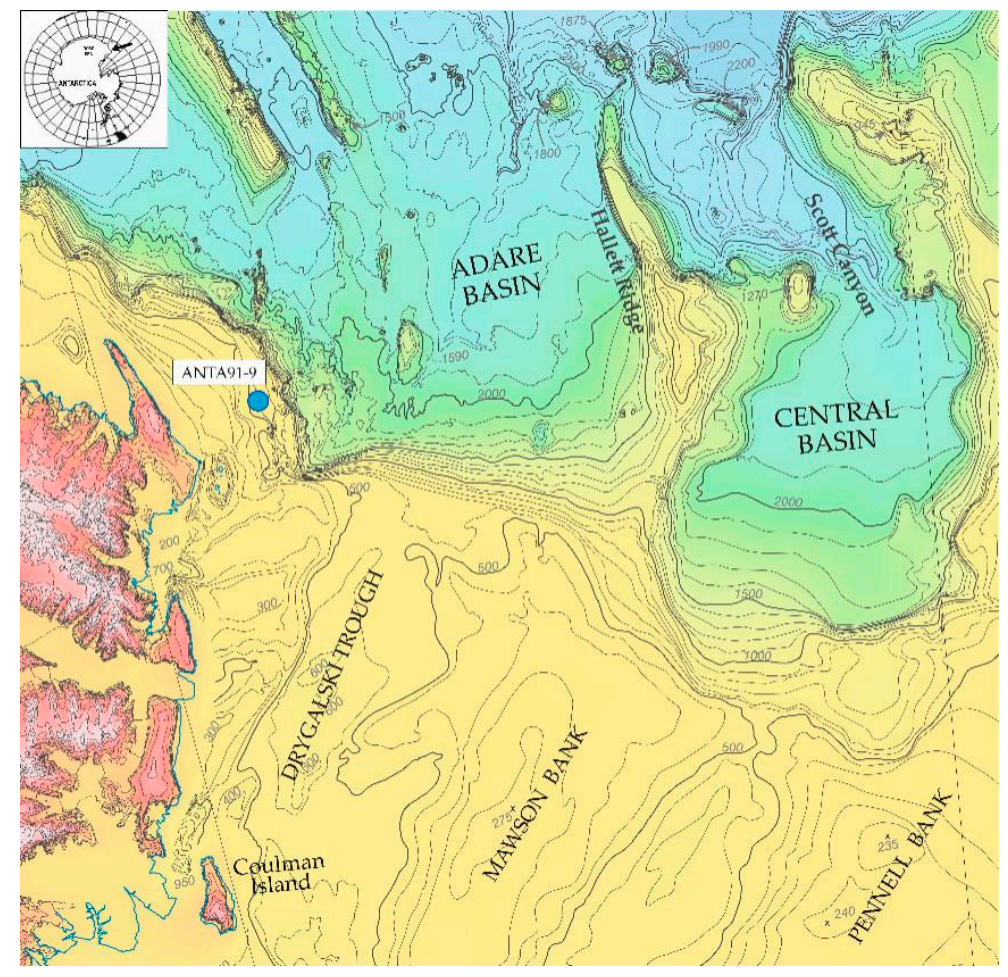

Figure 1. Location of the ANTA91-9 core. Ross Sea bathymetric map (after [26]), modified, showing the location of the named basins and banks.

The core had previously been halved, described and X-rayed by the authors of [8] and subsequently re-sampled in the laboratories of the Department of Mathematics and Geosciences, University of Trieste for this study. Forty-nine samples, each comprising approximately $1-2 \mathrm{~cm}$-thick core sections, were taken from along the core to examine sediment composition and micropaleontological assemblages (foraminifers and ostracods).

The samples for the micropaleontological analysis were first dried at $50{ }^{\circ} \mathrm{C}$, weighed, added with distilled water to separate the sediment and wet-sieved through a $50 \mu \mathrm{m}$ mesh sieve. 
Foraminifers were studied in the sediment fraction $>50 \mu \mathrm{m}$, using a binocular microscope. When the foraminifers were abundant, the samples were subdivided using a dry splitter until an aliquot containing approximately 300 specimens was obtained. The species counts were carried out on well preserved specimens and recorded as the number of specimens of each taxon; these data were subsequently converted into frequency expressed as a percentage. All foraminifers were identified at species levels, except for unilocular forms (Fissurina, Lagena and Oolina) and small Discorbidae, which have been identified at the generic level (Appendix A). The identification mainly follows [27-30]. The [31] was used for consultation of original taxa descriptions. From the total assemblage data, the measures of species diversity (Shannon Index, H) and dominance (D index) were calculated for each level using the PAST (version 4.03) (PAlaeontological STatistics) data analysis package [32].

The same samples used for the foraminifer analysis were used for the study of ostracods. They were studied in the sediment fraction > 50 to preserve not only the medium- or large-sized species but also the juvenile moults, which are important for the definition of the autochthonous or allochthonous assemblage conditions. This size fraction is also normally used for deep-sea ostracod research and allows us to obtain adults and late moult juveniles stage for most species [33,34]. All the valves and carapaces of the adult specimens found in the samples were collected, classified, and identified under a binocular microscope. The number of specimens refers to both valves and carapaces, i.e., one valve is considered to be one specimen and one articulated carapace is one specimen [33]. The identification mainly follows [33,35-43].

All foraminifer and ostracod species discussed in this study were deposited in the repository of the Department of Mathematics and Geosciences.

The study partially incorporates only some of the abiotic (i.e., water content and sediment grain-size) and biotic (foraminifers) data previously published in [8], while the majority of the levels were re-sampled to obtain thinner levels $(2 \mathrm{~cm}$ instead of $4-5 \mathrm{~cm}$, as originally used in [8]). The sandy fraction was analysed in a settling tube and the mud fraction on a Micromeritics ET 5000 Sedigraph. Total carbon (TC), total organic carbon (TOC) and total nitrogen (TN) content, in percentage, were detected as the mean value of 2 replicates of the same sample using an Elemental Analyzer (ECS 4010 CHNSO) and acetanilide as the standard for calibration. Large calcareous particles (>2 mm), such as fragments of bryozoans or entire bivalves, were excluded. To determine the TOC, prior to analysis the samples were progressively acidified with $\mathrm{HCl} \mathrm{0.1-1.0} \mathrm{N}$ [44]. TIC content obtained from TC and TOC measurements was used to calculate the $\mathrm{CaCO}_{3}$ content as weighted percentage by the multiplication of factor $8.333\left(\mathrm{CaCO}_{3} / \mathrm{C}\right.$ ratio $)$.

The chronology of the studied core is based on six new AMS radiocarbon dates obtained from mixed calcareous microfossils (foraminifers). We decided not to consider the ${ }^{14} \mathrm{C}$ date published by the authors of [8], indicating a conventional age of $23.1 \mathrm{ka} \pm 320$, since it was obtained using a mollusc without etching its surface to reveal the underlying fresh carbonate, as suggested in [10]. Since the radiocarbon analyses were carried out on mixed benthic organisms, which can show variable ${ }^{14} \mathrm{C}$ vital effect, the AMS ${ }^{14} \mathrm{C}$ dates were calibrated using a marine reservoir age with a relative larger error $(R+\Delta R=1100 \pm 200 y r)$, as suggested in [45]. The calibration of the radiocarbon dates was based on the MARINE 13 calibration curve [46] by means of Clam 2.3.2 [47] at 95\% confidence ranges. The Clam was also used to calculate the age-depth model through a linear interpolation function between dated levels with an amount of 1000 iterations (Figure 2). The uncorrected and calibrated ${ }^{14} \mathrm{C}$ data are reported in Table 1 ; all the ages reported in the rest of this paper are calibrated ages, unless otherwise specified.

In order to understand the distribution of the benthic foraminifer and ostracod assemblages along the studied core, their relative frequency was analysed with an orthogonal rotated (Varimax) Q-mode principal component analysis (PCA) using the XLstat package software, version 2019-1. As regards the foraminifers, the relative frequency of the taxa with occurrence at least $2 \%$ of the total assemblage in at least two samples was used. This procedure left 17 species and 9 genera, also combining the species with similar paleoenvironmental significance (i.e., Cibicides spp. and the unilocular taxa), 
for statistical analysis. The calculated PC scores indicate the contribution of the foraminifer species for each PC and, consequently, taxa pertaining to the same PC have been considered to have similar paleoenvironmental conditions. Only the PC loading which exceeded the value of 0.4 was considered statistically significant, as suggested in $[19,30,48,49]$. As regards the ostracods, the number of species was reduced to 43 , disregarding taxa with occurrence below $2 \%$ of the total assemblage in at least two samples or single occurrence species. The Polycope species (all in open nomenclature), found for the first time in Antarctic sedimentary series, which were subject the same trend within the levels of the ANTA91-9 core, have been joined at generic level. All ostracod taxa subjected to statistical analysis were previously standardized using the weight of the observed samples.

Table 1. AMS ${ }^{14} \mathrm{C}$ ages with calibrated calendar ages $\pm 2 \sigma(\mathrm{yr})$. The calendar ages are calibrated using the Clam 2.3.2 software [47] with Marine 13 calibration curve [46]. A constant reservoir correction of $1100 \pm 200$ years with a $\Delta \mathrm{R}$ of $700 \pm 200$ years was applied, as suggested in [45]. Calibrated age ranges at $95 \%$ confidence.

\begin{tabular}{|c|c|c|c|c|c|c|c|c|}
\hline $\begin{array}{c}\text { Core } \\
\text { Number }\end{array}$ & $\begin{array}{c}\text { Sample } \\
\text { Depth } \\
\text { (cm) }\end{array}$ & $\begin{array}{l}\text { Laboratory } \\
\text { Code }\end{array}$ & $\begin{array}{l}\text { Carbon } \\
\text { Source }\end{array}$ & $\begin{array}{l}\text { Conventional } \\
{ }^{14} \text { C Age (yr BP) }\end{array}$ & $\delta^{13} \mathrm{C}$ & $\begin{array}{c}\text { Calibrated }{ }^{14} \mathrm{C} \\
\text { Age (yr (BP) }\end{array}$ & $\operatorname{Min} 95 \%$ & $\operatorname{Max} 95 \%$ \\
\hline ANTA91-9 & $0-2$ & GX-23025 & foraminifers & $8900 \pm 60$ & -0.5 & 8736 & 8546 & 8927 \\
\hline ANTA91-9 & $28-30$ & GX-23026 & foraminifers & $13,510 \pm 80$ & -0.6 & 14,538 & 14,137 & 14,940 \\
\hline ANTA91-9 & $73-75$ & GX-23403 & foraminifers & $19,680 \pm 160$ & -3.6 & 22,439 & 21,844 & 23,019 \\
\hline ANTA91-9 & $153-155$ & GX-23027 & foraminifers & $14,690 \pm 80$ & 0.9 & 16,390 & 16,120 & 16,662 \\
\hline ANTA91-9 & $183-185$ & GX-23404 & foraminifers & $15,710 \pm 100$ & -1.3 & 17,776 & 17,531 & 18,022 \\
\hline ANTA91-9 & $315-316$ & OS-78316 & foraminifers & $19,000 \pm 70$ & n.d. & 21,672 & 21,451 & 21,894 \\
\hline ANTA91-9 & $407-408$ & Poz-122918 & benthic forams & $22,920 \pm 150$ & n.d. & 26,089 & 25,792 & 26,386 \\
\hline
\end{tabular}

GX = Geochorn entrprises (USA); OS = NOSAMS Wood Hole (USA); Poz = Poznan Laboratory (Polland).

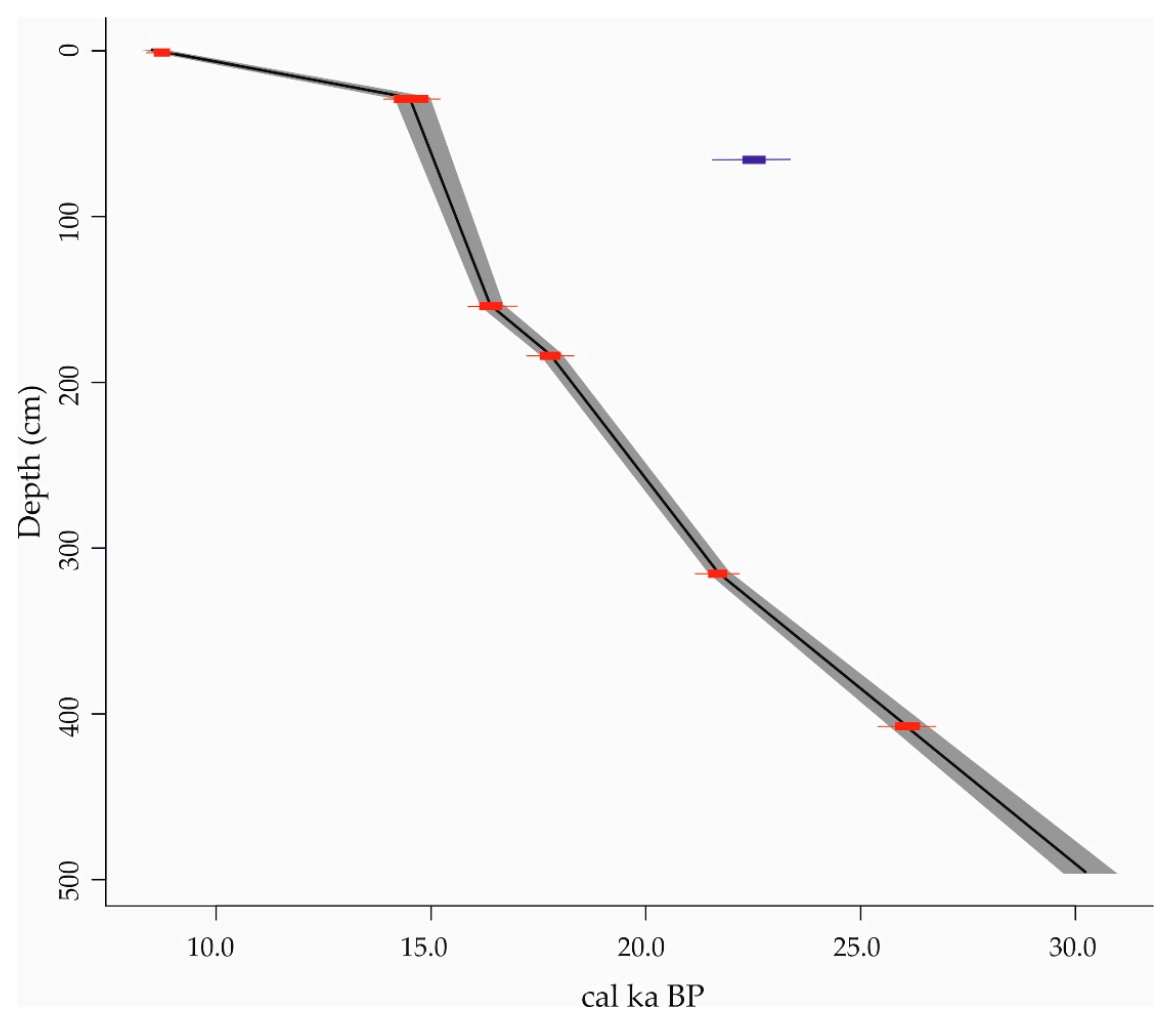

Figure 2. Age-depth model based on linear interpolation of best point calibration age from ${ }^{14} \mathrm{C}$ dates (in red) obtained using Clam software [47]. The color blue of the age at the depth of $73-75 \mathrm{~cm}$ corresponds to the level not included in the age model (see the following text for details). The gray envelope shows the $95 \%$ confidence intervals based on 1000 iterations. 


\section{Results}

All radiocarbon ages obtained, except one, are consistent with their stratigraphic position (Figure 2). The only date showing an age reversal is obtained in the upper part of the core (73-75 cm, Figure 1, Table 1). Age reversals are very common in Antarctic sediments subjected to the influence of bottom currents, gravitational phenomena or seafloor disturbances by icebergs or ice-shelf keels [10,12,13,45,50-52]. Considering the absence of sedimentary structures indicating slumping or gravitational phenomena in the interval where the reversed age level was found and that the depth of the core location was too high for the average depth of influence of icebergs [53], it is rather believed to be a problem due to the mixing of reworked sediments by bottom currents. Taking into account that all the other ages are in stratigraphic order and that the age model appears to work properly with the data discussions, it was decided to exclude the reverse data from the discussions.

The chronological reconstruction based on the calibrated ages corresponds to the time interval from late MIS2 to the early Holocene, including the Last Glacial Maximum (i.e., 19-26.5 ka BP, sensu [54]. Unfortunately, the top showed an age of $8.5 \mathrm{ka} \mathrm{BP}$, possibly indicating that part of the sediment was lost during core drilling (gravity core) or that the area is in fact subjected to strong currents capable of removing the most recent sediments. Overall, considering that the chronology was mainly obtained using in-situ well preserved calcareous foraminifers, we are confident that our age model is reliable.

\subsection{ANTA91-9 Lithofacies and Biofacies Composition}

Core ANTA91-9 consisted largely of siliciclastic sediments with variable amounts of carbonates. The grain-size analyses indicated that gravel content varied from 0.9 to $27.8 \%$ with a mean value of $14.2 \pm 6.3 \%$, sand from 15.1 to $78.4 \%$ with a mean value $35.3 \pm 11.9 \%$, and pelite $(<50 \mu \mathrm{m})$ from 11.7 to 84.0 with a mean value of $50.5 \pm 13.7 \%$ (Figure 3 ).

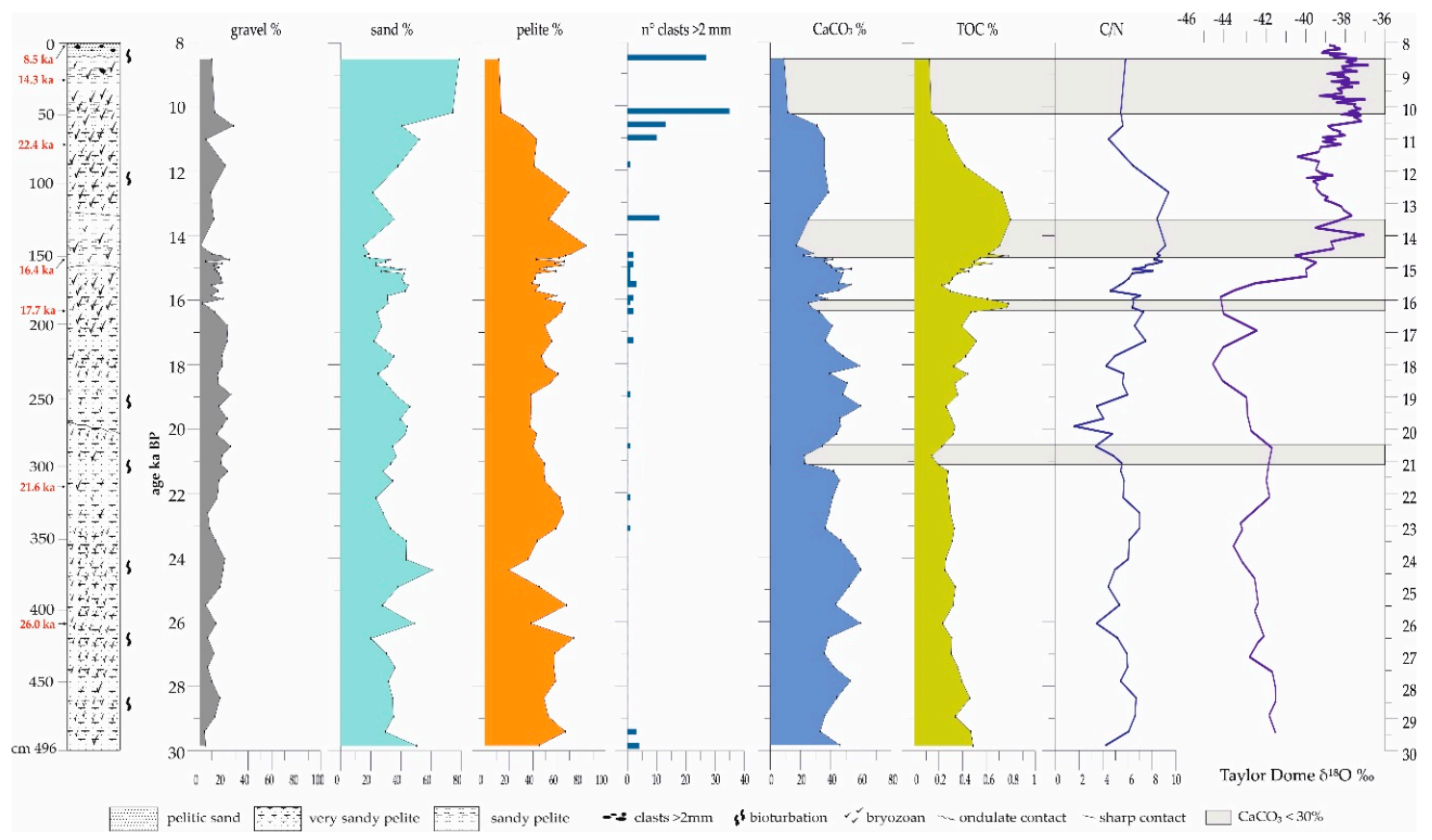

Figure 3. Texture and sediment geochemistry of the studied core. From left to right: down-core distribution of gravel (\%), sand (\%), pelite (\%), number of clasts $>2 \mathrm{~mm}$ in size, $\mathrm{CaCO}_{3}(\%)$, organic $\mathrm{C}(\%)$, $\mathrm{C}_{\text {org }} / \mathrm{N}_{\text {tot }}$ contents and $\delta^{18} \mathrm{O}$ in the Taylor Dome ice core, from [55], modified. The time scale (st9507) was used for $\delta^{18} \mathrm{O}$ data. There are a few textural data from [8], modified (see Methods). Authors elaboration Calibrated ages (ka BP) dated by AMS ${ }^{14} \mathrm{C}$ are reported in red (see Table 1 for details). The top level of this core dates to $8.5 \mathrm{ka}$ BP. Gray areas crossing $\mathrm{CaCO}_{3}$ and $\mathrm{TOC} \%, \mathrm{C} / \mathrm{N}$ and $\delta^{18} \mathrm{O}$ curves represent sediments with $\mathrm{CaCO}_{3}$ content $<30 \%$. 
Following the [56] classification, the sediments mainly pertain to very sandy pelite and sandy pelite, subordinately. Only the uppermost $10 \mathrm{~cm}$ of sediments, Holocene in age, are pelitic sand, in which the sand content is $>70 \%$ (Figure 3). In particular, sandy pelite characterises some intervals younger than $15.0 \mathrm{ka} \mathrm{BP}$, around $16 \mathrm{ka} \mathrm{BP}$ and other scattered levels mainly concentrated towards the bottom of the core. The gravel fraction is entirely composed of calcareous skeletal elements and tests except for the uppermost interval, from about $16 \mathrm{ka}$ BP upward, where an increase in inorganic clasts was recorded. Ice-rafted debris (IRD, clasts $>2 \mathrm{~mm}$ in size) were sporadically recovered in the core, but they significantly increased in sediments younger than $13.5 \mathrm{ka} \mathrm{BP}$ and, in particular, during the Holocene (Figure 3). IRD were often volcaniclastic in composition.

Total carbonate content in these sediments varied from 9.2 to $60.0 \%$ (mean value $39.6 \pm 11.3 \%$ ) in the fraction $<2 \mathrm{~mm}$ (Figure 3). TOC and TN varied from 0.13 to $0.80 \%$ (mean value $0.40 \pm 0.16 \%$ ) and from 0.03 to 0.25 (mean value $0.08 \pm 0.03 \%$ ), respectively. $\mathrm{C} / \mathrm{N}$ molar ratio varies from 1.6 to 9.4 with a mean value of $6.1 \pm 1.6$. TOC shows lower values in the older sediments, until $18 \mathrm{ka} \mathrm{BP}$, then increases with some oscillations at approximately $14 \mathrm{ka} \mathrm{BP}$ and then decreases again (Figure 3).

The studied sediments included bryozoans, serpulid polychaetes, barnacles, molluscs (also pteropods), very rare corals and brachiopods in the gravel (Table S1) and sand fractions, together with sand-sized benthic and planktonic foraminifers, ostracods and sponge spicule. Biogenic ash derived from these taxa completed the biogenic fraction. Bryozoans are present in all sediments and are the most abundant biogenic grain, followed by serpulids. Bryozoans are typically disarticulated or fragmented, but the elements are never abraded. Erect, articulated, robust cylindrical forms and encrusting forms are the most common. Articulated delicate cylindrical forms are subordinately present. The bioclasts were frequently encrusted by successive colonies of bryozoans or by serpulids, except for the Holocene interval and in the time interval at around $16 \mathrm{ka}$ BP.

These calcareous remains were distributed throughout the core with a chaotic disposition (Figure S1 in the supplementary), with the exception of three intervals, located at depth with age $<12.7,16.0-16.4$ and 20.5-21.2 ka BP, where a decrease in $\mathrm{CaCO}_{3}$ content and a relative increase in IRD is observed (Figure 3).

This biofacies assemblage is very close to the "muddy bryozoan/barnacle/pelecypod/foraminifers" assemblage described in [5] on the outer shelf/upper slope of the eastern flank of the Mawson Bank, and also shares similarities with the biogenic sediments of the southern coast of Australia [57,58]. Moreover, the studied core shows great similarity with Facies Association 2 (bryozoan gravel and variable muddy sand) and Facies Association 4 (microbioclastic sand) proposed by the authors of [10] for the carbonate sediments of the north-western Ross Sea shelf.

\subsection{Microfossils}

\subsubsection{Foraminifers}

Forty-eight benthic species representing thirty-seven genera were found (Table S2); some species of Fissurina, Lagena and Oolina were collectively grouped as species plurimae (spp.). Planktonic foraminifers were exclusively represented by Neogloboquadrina pachyderma, which was always present with two morphotypes, the thickened and encrusted type, typical for terminal life stage, and the thin-walled non-encrusted type, which is known to represent the early stage of the life cycle living in the surface water $[59,60]$. Among them, the encrusted morphotype (adult) is the dominant form, varying from 27.0 to $96.4 \%$ of their distribution and being generally over $50 \%$.

Benthic taxa were widely present throughout the core; among them, 23 species occurred in almost $90 \%$ of the studied levels and eight species were always present (Astrononion antarcticus, Discorbis vilardeboanus, Fissurina spp., Globocassidulina biora, Globocassidulina subglobosa, Lagena spp., Miliolinella subrotunda and Patellina antarctica) (Table S2). The foraminifers are generally very well preserved and the assemblages include a wide range of test sizes, except for very few levels in ages older than $18.0 \mathrm{ka}$ BP (at the 211, 265, $417 \mathrm{~cm}$ depth), where they show some size sorting. 
Among them, the most abundant species were, in decreasing order, $M$. subrotunda (mean value 9.4\%), D. vilardeboanus (m.v. 8.7\%), Epistominella exigua (m.v. 8.7\%), G. biora (m.v. 7.6\%), P. antarctica (m.v. 7.9\%) and Sigmoilina umbonata (m.v. 5.4\%). The down-core variation in their relative abundances (Figure 4) shows that G. biora was more abundant in the medium-uppermost sediments, while E. exigua was more abundant in the basal sediments and decreased upwards. Meanwhile, D. vilardeboanus tended to decrease upwards, and M. subrotunda and S. umbonata showed numerous peaks in abundance in the medium-basal part of the core and decreased upwards. Trifarina earlandi is significantly present in the basal part of the core and, lastly, P. antarctica showed a fluctuating distribution without any particular trend.

The benthos density (varying from 270 to 5166 specimens/g) was greater than the planktonic density (varying from 129 to 1218 specimens/g) (Figure 4). Overall, the foraminifer density increased from the bottom to the top, except for the youngest sediments where a strong decrease in the $\mathrm{CaCO}_{3}$ content corresponded to a decline in their density (Figure 3).

The five PC scores used in this study explain $86.5 \%$ of the total variance in the benthic foraminifer data set. These five most significant PCs are referred to as Foraminifer Associations (FAs) using the name of the dominant taxon (Table 2). The two main PCs are: E. exigua FA, with a high positive D. vilardeboanus score, explaining the variance of $31.4 \%$, and the M. subrotunda FA, with high positive S. umbonata and G. biora scores and a negative score of T. earlandi, explaining the variance of $27.8 \%$. Three additional FAs are considerably less widespread, that is the G. biora FA with high positive D. vilardeboanus and T. angulosa scores (variance of $10.8 \%$ ), the Tubinella funalis FA with a high positive G. subglobosa score and a negative Pyrgo spp. score (variance of $10.5 \%$ ) and Cibicides spp. FA (variance of $6.0 \%)$.

Table 2. Foraminifer Principal Component scores (FAs). The dominant species for particular FA are reported in bold.

\begin{tabular}{cccccc}
\hline & E. exigua & M. subrotunda & G. biora & T. funalis & Cibicides spp. \\
& FA & FA & FA & FA & FA \\
\hline Total variance explained (\%) & 31.4 & 27.8 & 10.8 & 10.5 & 6.0 \\
Astrononion spp. & -0.45 & -0.13 & -0.10 & -0.58 & -0.25 \\
Cibicides spp. & 0.11 & -0.19 & -0.25 & 0.92 & $\mathbf{4 . 2 8}$ \\
Cornuspira involvens & -0.57 & -0.08 & -0.27 & -0.04 & -0.86 \\
Discorbis vilardeboanus & $\mathbf{1 . 9 1}$ & 0.28 & $\mathbf{2 . 3 4}$ & -0.84 & -0.41 \\
Ehrembergina glabra & -0.24 & -0.34 & -0.61 & -0.86 & 0.48 \\
Entosolenia sp. & 0.13 & -0.33 & -0.05 & -0.87 & -0.02 \\
Epistominella exigua & $\mathbf{3 . 6 1}$ & -0.24 & -0.84 & -0.18 & -0.32 \\
Fissurina spp. & 0.00 & -0.26 & -0.59 & 0.96 & -0.10 \\
Globocassidulina biora & -1.39 & $\mathbf{1 . 8 4}$ & $\mathbf{3 . 4 1}$ & -0.02 & 0.46 \\
Globocassidulina subglobosa & -0.12 & -0.40 & -0.62 & $\mathbf{2 . 2 0}$ & 0.32 \\
Lagena spp. & -0.43 & -0.27 & -0.44 & -0.87 & -0.13 \\
Miliolinella subrotundata & 0.32 & $\mathbf{3 . 4 4}$ & -1.17 & 0.19 & 0.50 \\
Nonionella spp. & -0.04 & -0.54 & 0.62 & 0.87 & -1.19 \\
Oolina spp. & -0.27 & -0.16 & -0.62 & -0.70 & 0.02 \\
Patellina antarctica & $\mathbf{1 . 0 4}$ & 0.79 & 0.09 & $\mathbf{1 . 9 1}$ & -1.43 \\
Planispirinoides bucculentus & -0.76 & -0.39 & -0.56 & -0.85 & -0.07 \\
Pseudobulimina chapmani & -0.49 & -0.49 & -0.48 & -0.67 & -0.07 \\
Pullenia subcarinata & -0.51 & -0.54 & -0.46 & -0.72 & 0.12 \\
Pyrgo spp. & -0.70 & -0.61 & -0.42 & -0.94 & -0.26 \\
Rosalina globularis & 0.84 & -1.05 & 1.01 & 0.38 & 0.41 \\
Sigmoilina umbonata & 0.02 & $\mathbf{2 . 0 9}$ & -1.01 & -0.70 & -0.22 \\
Spirillina spp. & -0.83 & 0.35 & -0.14 & -0.12 & -0.81 \\
Trifarina earlandi costate & 0.91 & -0.98 & $\mathbf{1 . 0 7}$ & -1.14 & 0.87 \\
Triloculina trigonula & -0.53 & -0.05 & -0.51 & 0.44 & -0.44 \\
Trochammina multiloculata & -0.79 & -0.85 & 0.21 & -0.28 & -0.57 \\
Tubinella funalis & -0.76 & -0.87 & 0.38 & $\mathbf{2 . 5 2}$ & -0.32 \\
\hline
\end{tabular}



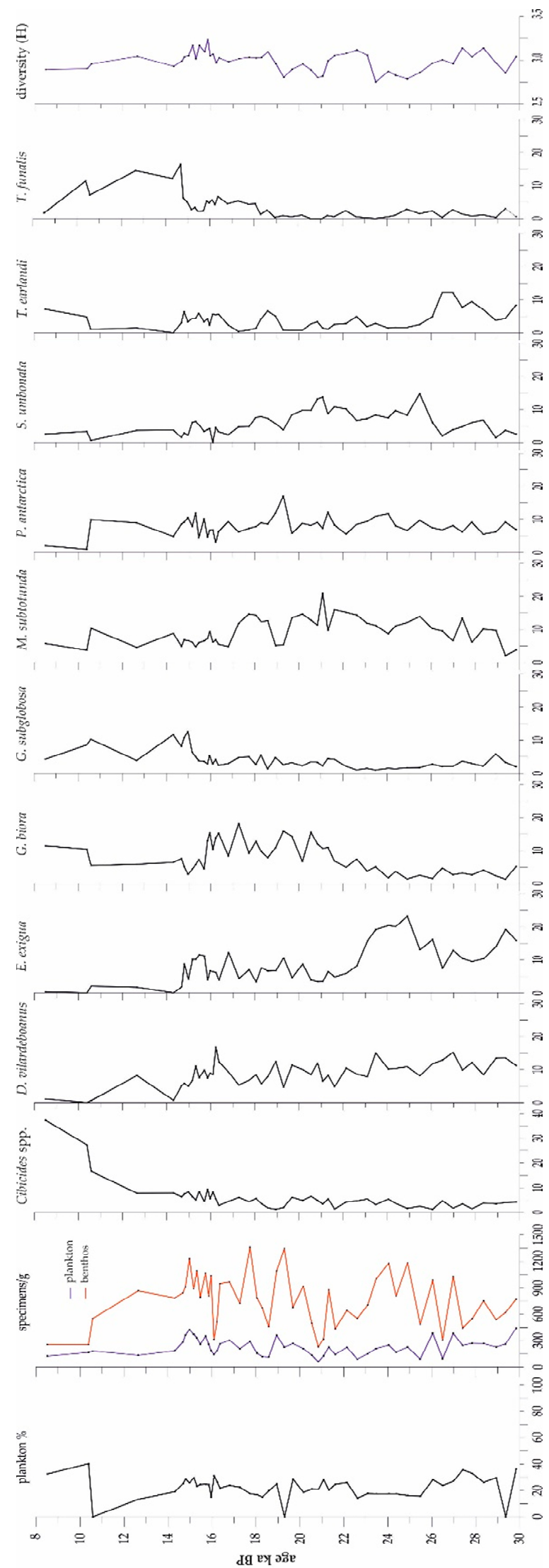

Figure 4. From left to right: down-core distribution of plankton \%, plankton/g (in blue) and benthos/g (in red) of dry sediment, relative abundance (\%) of significant benthic foraminifers and Shannon Diversity Index $(\mathrm{H})$. 


\subsubsection{Ostracods}

The ostracod podocopid fauna from the studied core is represented by 54 species belonging to 35 genera (Table S3). Of the 54 species, 19 are recorded in open nomenclature. The ostracod assemblage is dominated by the cytheracean taxa. Some species were represented by only a few specimens, while others contained more numerous populations. Faunas are well preserved.

The most abundant species are Australicythere devexa, Australicythere polylyca, Bairdoppilata simplex, Cytheropteron (Loxoreticulatum) fallax, Patagonacythere longiducta, Pseudocythere aff. P. caudata and Xestoleberis rigusa, other taxa represented by Antarcticythere laevior, Cytheropteron sp., Hemicytherura spp., Polycope spp. and Sclerochilus reniformis show lesser quantitative values (Figure A1, Figure A2). In particular, A. devexa, B. simplex, P. aff. P. caudata and X. rigusa show higher peaks in the upper and middle basal core levels. The lower levels are characterised by an evident decrease in the above-mentioned species. Cytheropteron (Loxoreticulatum) fallax reaches the highest values in the medium-upper levels of the core in contrast to A. polylyca, which shows the highest contents in basal levels. As regards the values relative to the number of species, number of specimens/g and of the Shannon index $(\mathrm{H})$, variable values are observed, dividing the core into precise intervals. In particular, high $\mathrm{H}$ values were recorded in the following intervals (Figure 5): younger than 15.3, 17.1-19.1, 20.9-24.3 and 25.2-28.1 ka BP, while intervals characterised by lower values were recorded at $<10.2,15.4-16.7,19.4-20.6$ and 28.5-29.5 ka BP.

The four PC scores used in this study account for $78.4 \%$ of the total variance in the ostracod data set. All PCs are defined by a species with the highest positive PC scores (Table 3). In three cases, they are accompanied by taxa with lower, but still significant scores, contributing to the definition of the particular assemblage. In the following discussion, the calculated PCs (mathematical models of real assemblages), are referred to as ostracod assemblages (OAs) using the name of the dominant taxon. The four PCs are: $1-$ Pseudocythere aff. P. caudata OA (variance of $27.5 \%$, with Australycythere devexa, Kangarina sp., high positive scores), 2-Cytheropteron fallax OA (variance of 22.4\%), 3-Bairdoppilata simplex OA (variance of 20.7\%, with Australycythere devexa and Xestoleberis rigusa high positive scores), 4-Australicythere polylyca OA (variance of $7.8 \%$ ). 
Table 3. Ostracods Principal Component scores (OAs). The dominant species for particular OA are reported in bold.

\begin{tabular}{|c|c|c|c|c|}
\hline & $\begin{array}{l}\text { P. caudata } \\
\text { OA }\end{array}$ & $\begin{array}{l}\text { C. fallax } \\
\text { OA }\end{array}$ & $\begin{array}{l}\text { B. simplex } \\
\text { OA }\end{array}$ & $\begin{array}{c}\text { A. polylyca } \\
\text { OA }\end{array}$ \\
\hline Total variance explained (\%) & 27.5 & 22.4 & 20.7 & 7.8 \\
\hline Aglaiella setigera & 0.08 & -0.20 & 0.16 & -0.25 \\
\hline Antarcticythere laevior & 0.81 & -0.32 & -0.19 & 0.07 \\
\hline Antarctiloxoconcha frigida & -0.37 & -0.37 & -0.23 & 0.13 \\
\hline Argilloecia antarctica & -0.21 & -0.49 & 0.09 & -0.30 \\
\hline Argilloecia spp. & -0.30 & -0.47 & 0.05 & -0.22 \\
\hline Australicythere devexa & 2.85 & 1.59 & 3.16 & 2.40 \\
\hline Australicythere polylyca & -0.85 & 0.19 & -0.09 & 5.41 \\
\hline Austrocythere reticulotuberculata & -0.46 & -0.40 & -0.19 & -0.03 \\
\hline Austrotrachyleberis antarctica & -0.44 & -0.43 & -0.21 & 0.17 \\
\hline Aversovalva antarctica & -0.52 & -0.30 & -0.18 & -0.08 \\
\hline Bairdia sp. & -0.43 & -0.34 & 0.23 & -0.43 \\
\hline Bairdoppilata simplex & -0.52 & -0.05 & 4.35 & -1.71 \\
\hline Bythoceratina dubia & -0.50 & -0.33 & -0.11 & -0.04 \\
\hline Cativella bensoni & -0.44 & -0.30 & -0.25 & -0.02 \\
\hline Convexochilus meridionalis & -0.47 & -0.19 & -0.25 & 0.08 \\
\hline Cytherois sp. & -0.43 & -0.37 & -0.20 & -0.09 \\
\hline Cytheropteron (Loxoreticulatum) fallax & -1.71 & 5.89 & -0.65 & -0.87 \\
\hline Cytheropteron abyssorum & -0.53 & -0.21 & -0.21 & -0.10 \\
\hline Cytheropteron antarcticum & -0.45 & -0.44 & -0.05 & -0.15 \\
\hline Cytheropteron gaussi & -0.42 & 0.36 & -0.33 & 0.17 \\
\hline Glacioloxoconcha suedshetlandensis & -0.22 & -0.18 & -0.40 & -0.10 \\
\hline Hemicytherura anomala & -0.29 & -0.19 & -0.15 & 0.09 \\
\hline Hemicytherura irregularis & 1.00 & 0.52 & -0.81 & 0.16 \\
\hline Kangarina sp. & 2.54 & -0.73 & -1.15 & 0.03 \\
\hline Krithe (Austrokrithe) magna & -0.55 & -0.26 & -0.11 & -0.07 \\
\hline Macropyxis similis & -0.02 & -0.36 & -0.05 & -0.32 \\
\hline Microcythere frigida & -0.32 & -0.35 & -0.25 & -0.05 \\
\hline Microcythere scaphoides & -0.29 & -0.34 & -0.20 & -0.24 \\
\hline Monoceratina sp. & -0.51 & -0.36 & -0.17 & -0.07 \\
\hline Orthopolycope antarctica & 0.00 & -0.49 & -0.32 & -0.09 \\
\hline Paracytheridea antarctica & -0.20 & -0.22 & -0.32 & -0.11 \\
\hline Paracytherois sp. & 0.55 & -0.19 & -0.61 & -0.42 \\
\hline Paradoxostoma hypselum & -0.30 & 0.08 & -0.33 & -0.35 \\
\hline Paradoxostoma spp. & 0.05 & 0.03 & -0.49 & -0.36 \\
\hline Patagonacythere longiducta & -0.70 & 0.13 & 1.12 & 0.13 \\
\hline Polycope spp. & 0.71 & -0.16 & -0.31 & -0.41 \\
\hline Pseudocythere aff. P. caudata & 4.00 & 1.25 & -1.65 & -1.07 \\
\hline Sclerochilus (Praesclerochilus) antarcticus & -0.36 & -0.33 & -0.15 & 0.07 \\
\hline Sclerochilus (Praesclerochilus) reniformis & 0.45 & 0.19 & -0.30 & 0.69 \\
\hline Semicytherura costellata & -0.44 & -0.15 & -0.24 & -0.17 \\
\hline Semicytherura sp. & -0.50 & -0.25 & -0.14 & -0.05 \\
\hline Xestoleberis rigusa & 1.00 & -0.27 & 2.33 & -1.08 \\
\hline Xiphichilus gracilis & -0.30 & -0.22 & -0.20 & -0.32 \\
\hline
\end{tabular}



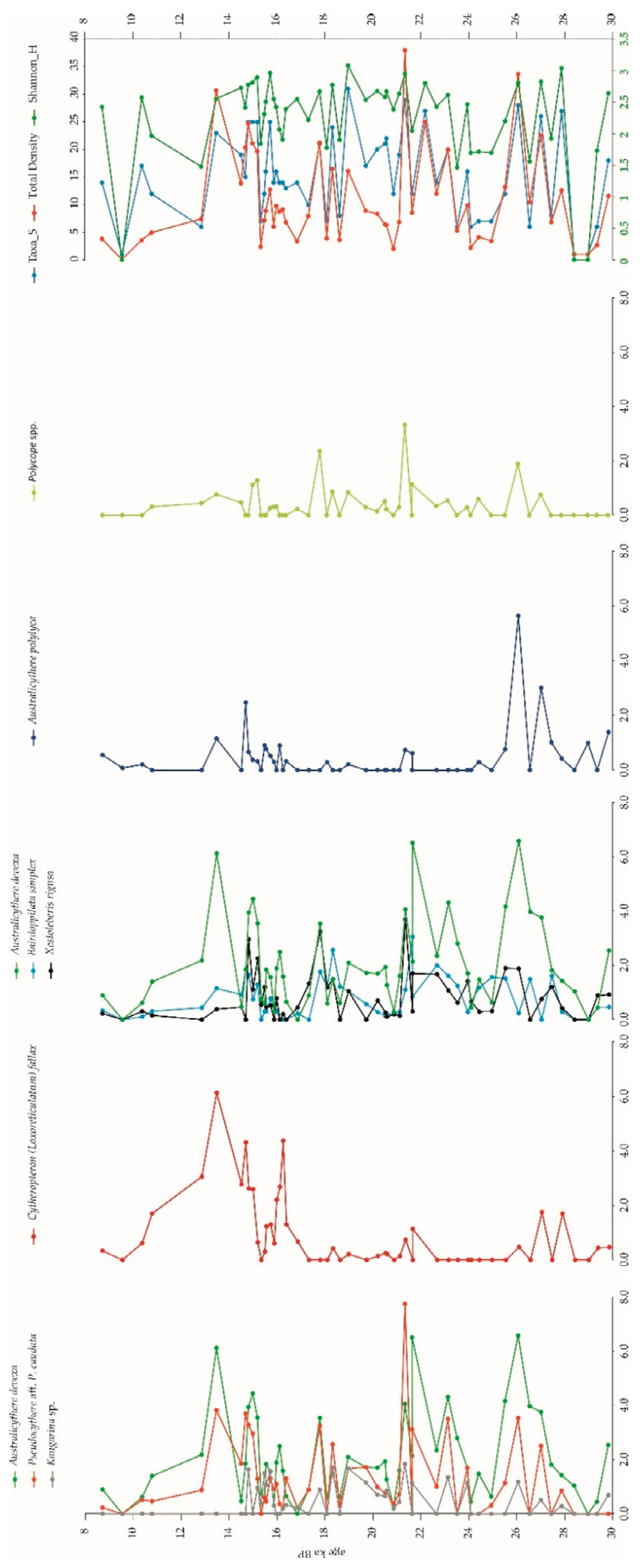

Figure 5. Main Ostracod species abundances ( $>50 \mu \mathrm{m}$ fraction) in number of specimens per gram of dry sediment in core ANTA91-09. Species Richness (S), Total Density (i.e., the number of individuals in each sample) (upper values axis—shown in black), and the Shannon Diversity Index (lower values axes-shown in green) are also reported. 


\section{Discussion}

\subsection{The Carbonate Factory}

The analysis of the foraminifer and ostracod assemblages in core ANTA91-9, collected in the area where the carbonate factories operated, offered us a possible interpretation of some paleoenvironmental/climatic events that have affected this area of the Ross Sea over the last $30 \mathrm{ka}$, while considering with caution the results obtained by a single sedimentary series. The deglaciation of the Ross Sea has proven controversial in terms of its timing (pre-global LGM or post-13 ka), style ("swinging gate" or "saloon door") (see discussion in [14]) and the forcing factors that regulate the ice retreat [61]. Recent articles from [52,62] made significant advances toward reconstructing an accurate ice sheet/ice shelf retreat history for the western Ross Sea by using a combination of geomorphic, sedimentological, and micropaleontological analyses to identify key sediment facies and transitions that mark grounding-line retreat and open-marine onset. Throughout the range of ages from the proximal glaciomarine sediments of the LGM grounding-zone wedges, the authors of [52] recorded that the ice reached its maximum extent at $25.6 \mathrm{ka} \mathrm{BP}$ and persisted for $\sim 14 \mathrm{ka}$ until $11.5 \mathrm{ka}$ BP.

The radiocarbon ages of the studied core indicate that the carbonate factory off the Cape Adare area was active by approximately $30 \mathrm{ka}$ BP until the early Holocene, including the Last Glacial Maximum (LGM) when widespread glaciations affected most of the Ross Sea continental shelf $[13,14,63,64]$ and the global mean sea level was $\sim 130-140 \mathrm{~m}$ lower than present [65] and references therein. This highlights that the outer sector of the western continental shelf was not covered by either grounded or floating ice during this period, in agreement with $[13,14,52,66]$. Conversely, predominantly terrigenous sandy sediments characterise the Late Pleistocene-Holocene transition of this area; the thickness of this interval is limited to the top sediments, $10 \mathrm{~cm}$-thick. This limited thickness could possibly be also attributed to the use of a gravity corer for the drilling operation.

Biogenic facies characterise the greater part of the studied sedimentary sequence, which shows strong affinity with the sediments recovered by the authors of [5] from the outer shelf of eastern flank of the Mawson Bank (western Ross Sea). In any case, the biogenic sediments of core ANTA91-9 are generally younger than the sedimentary sequences studied in $[5,10]$ and lack strong evidence of current influence, as generally reported by the authors of [22-25] for this region. Considering the overall preservation of the skeletal structures of the studied core biofacies, the almost total absence of abrasion in the biogenic remains and their general chaotic disposition, it can be deduced that most of these organisms have been subject to a moderate hydrodynamic bottom energy after their deposition. This biogenic sediment is unconsolidated and lacks chemical alteration, like cementation and/or dissolution, indicating that the seafloor diagenesis on the Ross Sea shelf was minor, in agreement with [11]. Furthermore, among the biological processes affecting these skeletal gravels, the bryozoans are very often encrusted by other colonies of bryozoans or serpulids. This fact likely suggests that the sedimentation had moments of stasis and therefore the biogenic material served as rigid substrate for subsequent colonies of encrusting organisms.

Studies regarding the present distribution of taxa such as bryozoans, molluscs and corals in the Cape Adare area are very scarce and mainly concern the stylasterid corals $[67,68]$. A present-day bryozoan assemblage similar to that recovered in core ANTA91-9 was described in [55] at the Pennell Bank and surrounding areas as a "Deep Shelf Mud Bottom Assemblage", at depths of 400-700 m. Similar bioclastic-rich sediments also occur on the upper continental slope of the George V, Terre Adélie continental margin, East Antarctica [4], where it has been suggested that these bryozoan-rich sediments could represent in situ accumulation. Shelf edge sectors of these high latitude areas are also considered suitable for sustaining organisms such as bryozoans, being zones of nutrient-rich upwelling currents [69]. These conditions could support extensive aphotic biostromal/hermal and bryozoan/sponge/coral communities, which generate thick successions of muddy biogenic sands, as reported in [57].

According to [10], the significant occurrence of bryozoans is indicative of a carbonate factory coeval with the glacial expansion of the LGM. The biogenic production/accumulation of the studied 
core matches with Facies Associations (FA) 2.3 and 2.4 proposed by the authors of [10], and seems to operate during the intervals 10.6-12.7, 14.7-15.7, 17.7-20.5 ka BP and in the sediments older than $21.3 \mathrm{ka} \mathrm{BP}$, including the last part of MIS3 and all of MIS2. Contrary to what [10] reported, who pointed to a gap in their cores between 22.7 and $3.6 \mathrm{ka} \mathrm{BP}$ (not calibrated ages), in this sector of Cape Adare, the carbonate factory continued to be productive also during the deglacial phases following the LGM.

The consistent occurrence of pelite in the shell lags of this core likely indicates that the effect of the currents with evidence of mud winnowing suggested in [10] was largely reduced in the studied site, on the contrary showing that normal open-marine sedimentation occurred during (or after) the biogenic production/accumulation. In this situation, the colonisation by species of foraminifers and ostracods, including epibionts and endobionts, capable of occupying sedimentary interstices, could occur, as reported in [9] in another biogenic sequence of the Victoria Land Basin area.

The deposition of bioclastic core sediments showed a temporary interruption at 8.5-10.2, 13.5-14.7, 16.0-16.4, and approximately 20.5-21.1 ka BP in relation to the inflow of more terrigenous sediments, bringing the $\mathrm{CaCO}_{3}$ content to values $<30 \%$ (Figure 3). We believe that these levels, which interrupt the carbonate factory, are therefore evidence of reducing ice volume or phases of instability/retreat of the ice sheet/shelf southward. In the Antarctic region, the post-LGM deglaciation is generally considered to start around $18 \mathrm{ka} \mathrm{BP} \mathrm{[13]} \mathrm{in} \mathrm{response} \mathrm{to} \mathrm{atmospheric} \mathrm{warming} \mathrm{[70].} \mathrm{However,} \mathrm{the} \mathrm{timing}$ and pattern of post-LGM ice-sheet retreat in Antarctica is ambiguous, and in many areas not well constrained. The first lowering of carbonate content at approximately $21 \mathrm{ka}$ BP could evidence the beginning of the deglaciation during the last part of the LGM. This phase corresponds to a light $\delta^{18} \mathrm{O}$ decrease in the Taylor Dome record (Figure 3) [71]. The other terrigenous intervals, roughly at about 14 and $10 \mathrm{ka} \mathrm{BP}$, likely correspond to the Melt Water Pulse (MWP)-1A event and to the final part of the MWP-1B event, which are both well recorded in coral records from Barbados Island [72], but not widely recognised in Antarctica. The MWP-1A corresponds to the Antarctic Isotope Maximum 1 recorded in Antarctic ice cores [73] and it is evidence of a continuous warming also seen in Taylor Dome (Figure 3) [55]. MWP-1B likely corresponds to Termination 1B and leads to heating representing the Antarctic early Holocene Optimum (AHO) evidenced in [74] at 9-11 ka BP.

Modelling experiments proposed by the authors of $[75,76]$ propose rapid ice mass loss mainly between 14.5-14.0 and 11.6-10.2 ka BP related to the increasing ocean temperature and, conversely, a period of Antarctic ice loss halt from 13.1 to $11.8 \mathrm{ka}$ BP. The terrigenous levels recorded in the core ANTA91-9 at $14 \mathrm{ka}$ BP correspond well to the rapid ice-mass loss hypothesised in [75,76], while the more recent terrigenous levels take on a younger age than that attributed to MWP-1B, but are closer to representing Antarctic early Holocene Optimum (AHO) (9-11 ka BP), which is synchronous in the marine records of the South Ocean Pacific sector [74] and references therein and which, in any case, represents a phase of warming and therefore sediment release. Considering the presence of the erosive contact at the passage between the carbonate and terrigenous sediments at the top of the core (Figure 3), some of the sediments related to MWP-1B may have been removed and, in addition, the age attributed to the increased contribution of the terrigenous material at the top of the core may be influenced by the approximation of the age model (linear interpolation). The younger sandy terrigenous levels of the studied core can also be interpreted as evidence of an increasing circulation of water masses, likely the HHSW. The erosive contact with the underlying muddy sediments indicates the beginning of the strong bottom-currents, which currently characterise this sector of the outer shelf at approximately $10.6 \mathrm{ka}$ BP. The fine fraction of the sediments was possibly winnowed by the currents, yielding residual glacial-marine sediments.

\subsection{The Microfossils}

In terms of microfossil content, the foraminifers and ostracods are very abundant, diversified and generally very well preserved. The great majority of the tests are complete, transparent and without sediment infill. Adult ostracods are often accompanied by their young moltings. On the basis of these observations, the microfossils discussed below have been generally considered in situ. 
The foraminifers observed in the core have been recognised as living in several modern Antarctic environments, from the inner shelf (e.g., D. vilardeboanus, miliolids in general, P. antarctica and R. globularis) to the upper slope-bathyal zone (for example, E. exigua, Globocassidulina spp., Pullenia subcarinata and T. earlandi) $[27,28,49,77-83]$. Species such as G. biora, G. subglobosa and T. earlandi are commonly used to recognise the sub-ice shelf facies, from proximal to distal, in studying glacial dynamics during the Late Quaternary $[18,19,30,62,84]$. Furthermore, Cibicides spp., are indicative of intense bottom water activity and they are abundant in the sandy sediments [85-87]. The diversity ( $\mathrm{H}$ index) of the benthic foraminifer assemblage is always high ( $>3.0)$, indicating stable paleoenvironmental conditions, except for at levels where a decrease in carbonate content is reported (Figure 4). In these levels, the $\mathrm{H}$ value decreased to <3.0, representing decreases in species richness and foraminifer density under increased terrigenous sedimentation. Here the assemblage is dominated by E. exigua and S. umbonata at the base of the core (influence of Antarctic Bottom Water currents, AABW or some evidence of the CDW), G. biora and M. subrotunda in the middle part of the core and Cibicides spp. at the top of the core (strong hydrodynamics, sandy texture). The occurrence of planktonic foraminifers is indicative of non-favourable surface water conditions, likely having been affected by general sea ice conditions. The increasing planktonic frequency toward the top of the core could indicate open marine conditions similar to nowadays.

In the Southern Ocean, ostracod research has mainly focused on recent ostracods up to now, i.e., those studies done by the authors of $[33,34,37-43]$. On the contrary, investigations on ostracods in sediment cores are rare in Antarctic seas [8,88-91], due to their poor preservation in corrosive bottom waters [13]. The ostracod assemblage of core ANTA91-9 is mainly composed of species previously described from various Antarctic and Subantarctic locations, from shallow to outer shelf zones $[33,35,36,39,40]$.

In particular, A. polylyca, a species characterised by a wide and robust shell, was widely recorded from the modern Antarctic region $[35,36]$. Cytheropteron fallax, widespread in the Antarctic (Elephant Island, Livingston Island, King George Island, Joinville Island, D'Urville Island, Lavoisier Island, Adelaide Island) in relatively shallow water [39], is signaled as characteristic of shallow depth often in association with phytal taxa or filter feeders, deposit feeders and predators/scavengers taxa [33,43]. Genus Xestoleberis has been recorded such as phytal taxa in $[33,92,93]$ in particular from the west coast of the Antarctic Peninsula (Paradise Bay) in shallow water and from the Halley Bay from a depth of $200 \mathrm{~m}$. Pseudocythere aff. P. caudata, rare in Admiralty Bay, is an Antarctic cosmopolitan species [42]. Dingle [89] highlights the presence/absence of the different species based on the depth and temperature of the water. Whatley et al. [92,93] reported the occurrence of some species such as Austrotrachyleberis antarctica, A. devexa and B. simplex at lower depths than usual as a probable cause of the concomitant presence of upwelling currents of cold and deep waters. In the same way, the authors of [94] link the presence of species both to the depth and the water masses and, in particular, to the Antarctic Intermediate Water, which has allowed some species to extend their presence to an unusually shallow limit.

\subsection{Foraminifer Associations (FAs) in the Carbonate Factory Environment}

Using the benthic foraminifers, five FAs recognised by the PCA analysis explain the total variance of $86.5 \%$ (Table 2). They are defined each by a single taxon with the highest positive PC scores and, in all cases, they are represented by calcareous assemblages.

\subsubsection{Epistominella Exigua FA}

This FA shows the highest $\%$ of variance. It has significant loadings (that is $>0.4$ ) from 14.8 to $16.8 \mathrm{cal} \mathrm{ka} \mathrm{BP}$, around 18.8 and $20.0 \mathrm{ka} \mathrm{BP}$ and in all sediments older than $22.0 \mathrm{cal} \mathrm{ka}$ BP (Figure 6a). This distribution generally coincides with the interval with the higher $\mathrm{CaCO}_{3}$ percentage. However, the E. exigua $\mathrm{FA}$ is not significant in the more recent carbonate sediments where there is a stable increase in TOC content. 


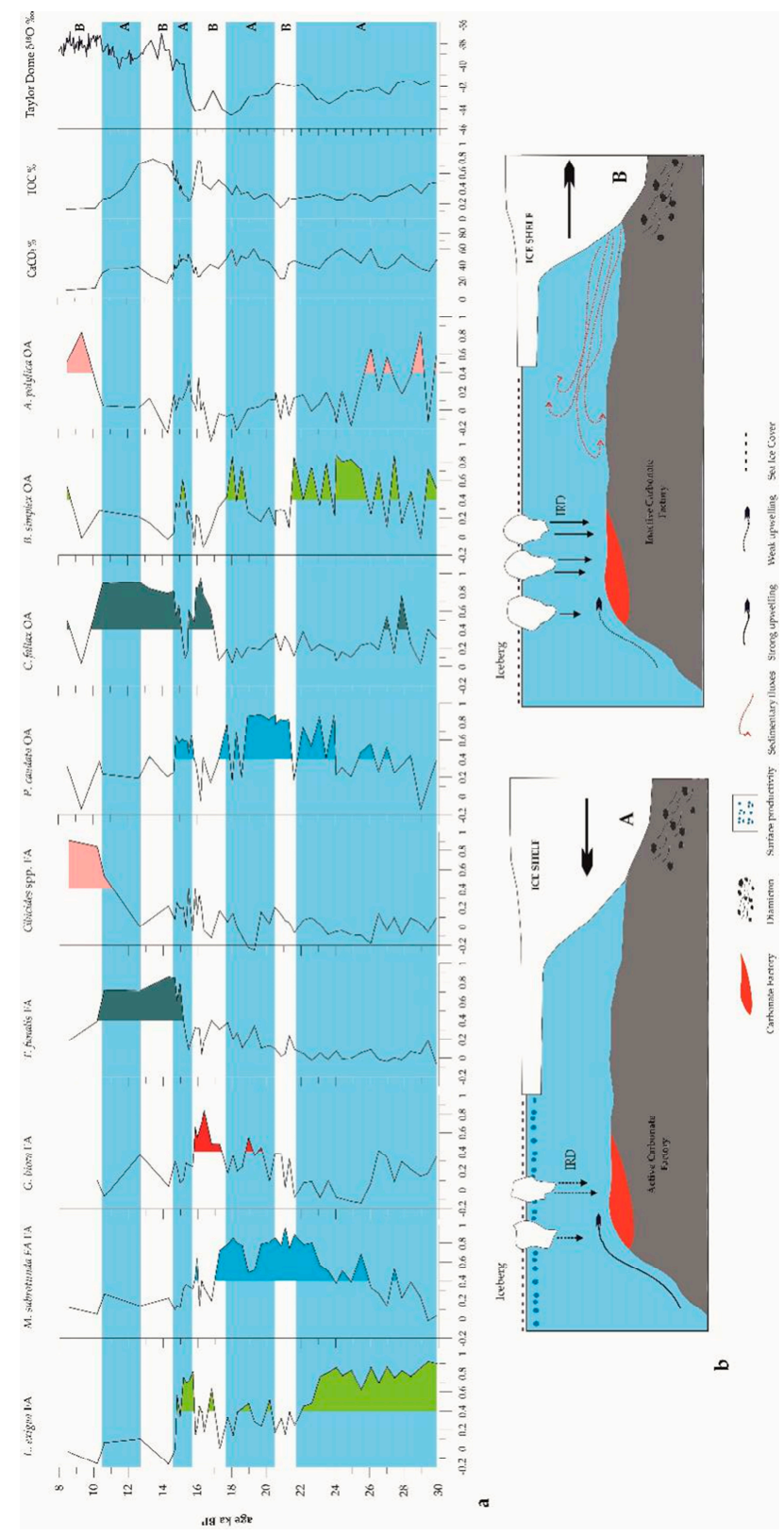

Figure 6. (a) Down-core distribution of the foraminiferal (FAs) and ostracod assemblages (OAs) based on the Principal Component Analysis (statistically significant loading values $>0.4$, as suggested in [48], are depicted using various colours) together with the percentage values of $\mathrm{CaCO}_{3}$ and $\mathrm{TOC}$ and $\delta^{18} \mathrm{O}$ curve. Blue areas (letter A) and uncoloured areas (letter B) depict, respectively, the advance and the retreat glacial phases, which affected the Cape Adare area from 30.0 ka up to the definitive Holocene glacial retreat (up to $11.0 \mathrm{ka} \mathrm{BP}$ ). (b) Paleoenvironmental reconstruction of the carbonate deposition at the Cape Adare area, northwestern Ross Sea, Antarctica, modified from [10], in relation to the ice shelf variations, using the results from FAs, OAs and abiotic data. A-Active carbonate factory. The expansion of the ice shelf inhibits the contributions of the terrigenous material, allowing a development of the carbonate factory. At the same time, the expansion of the sea ice reduces the influence of bottom currents and disturbance of the bottom communities caused by the transit of icebergs (high IRD, scouring phenomena). During the period of glacial expansion, there is an increase in nutrient fluxes resulting from increased upwelling (high CDW). B-Inactive carbonate factory. The withdrawal phases of the ice shelf generate high flows of sedimentary material from the melt water runoff and iceberg detachment, which reduces the deposition of the carbonate material. Some decreased flows of organic material are likely to be caused by a possible concomitant reduced CDW activity. 
Epistominella exigua is a small taxon generally occurring in the deep Atlantic and upper slope-bathyal Southern Ocean under the influence of the AABW $[79,95]$. Furthermore, it is considered an opportunistic species (r-strategist) able to feed on fresh phytodetritus $[85,96,97]$ and adapted to fluctuating food supply in areas where sea ice hinders the seasonal accumulation of phytodetritus. In the studied core, this FA may has recorded different periods of extended sea ice cover (or open marine conditions with seasonal sea-ice cover). Another possibility is that this small species may indicate the occasional influence of the CDW. In fact, it is thought that this species may be related to these warmer waters, as suggested in [19,49]. The lowest presence of E. exigua FA has been reported in the last $10 \mathrm{ka}$. Here the highest occurrence of the robust Cibicides refulgens testifies to the increasing hydrodynamics of the bottom waters where E. exigua cannot live.

Discorbis vilardeboanus and P. antarctica are other significant species of this FA. In polar areas, they are rarely recorded or found in very small quantities. They are both epifaunal, living on hard substrate and typically reported from the inner shelf [86]. However, P. antarctica is present in slope areas of the Scotia Sea, even if very scarce [98]. In this association, they could represent good conditions to live on the hard calcareous substrate.

\subsubsection{Miliolinella Subrotunda FA}

This FA has significant loadings at around $16 \mathrm{ka}$ BP and 17.2 to $26.0 \mathrm{ka}$ BP and occasionally in the older sediments (Figure 6a). It is associated with Sigmolilina umbonata and, in a more limited way, with G. biora. The distribution of this FA mainly corresponds to the lower TOC content, except for the level at $16 \mathrm{ka}$ BP. Miliolinella subrotunda is a species typically reported from the inner shelf of the Ross Sea area $[27,77,78]$ and its significant occurrence until $16 \mathrm{ka}$ BP could represent shallower paleobathymetry conditions. This condition is compatible with the period when the global mean sea level was $130-140 \mathrm{~m}$ lower than present [65]. The significant occurrence of S. umbonata and P. corrugata, also occurring in shelf environments $[27,77,78]$, could also provide evidence for the influence of weak currents able to transport these small taxa in suspension. The presence of G. biora, although with secondary scores respecting the other two species, could suggest a certain glacial influence, including cold-water conditions and elevated or variable sedimentation rates $[19,29,99]$. Further details on this species are reported in the following FA.

\subsubsection{Globocassisulina Biora FA}

This FA has significant loading from 15.9 to $17.2 \mathrm{ka}$ BP and from 18.9 to $20.8 \mathrm{ka}$ BP only (Figure 6). This assemblage corresponds to lower $\mathrm{H}$ index values and is indicative of intervals with lower $\mathrm{CaCO}_{3}$ contents (Figure 3). Globocassidulina biora has recently been studied by the authors of [100] from the morphological and molecular point of view. When this species reaches larger sizes, the aperture character (i.e., double parallel aperture) is easily recognisable, but, on the contrary, when the specimens are still young they can be confused with G. subglobosa or G. crassa rossensis. The majority of morphological variability observed among G. biora in Admiralty Bay by the authors of [100] may be the result of observing specimens at different growth stages. In the studied core, we found mainly minute, thin-walled specimens of this genus (type 4, small forms with a single aperture, sensu [100]), which is common in the north-western Ross Sea as opposed to the south-western Ross Sea and Whales Deep Basin, where larger specimens dominate, indicating closer ice-proximal conditions [19,30]. The dominant species of this FA, G. biora with T. earlandi, normally live in Antarctic fjords and continental shelf settings from coastal to outer shelf bathymetry $[29,83,85,101]$. Globocassidulina biora, together with G. subglobosa, Nonionella spp., and T. earlandi, are commonly used to recognise the past sub-ice shelf facies (from proximal to distal) as indicative of a strong glacial influence $[18,20,30,62,84,99]$. We believe that this FA represents conditions of elevated or variable terrigenous sedimentation rates, indicating ice instability. 


\subsubsection{Tubinella Funalis FA}

This FA is consistent in the time interval 10.8-15.0 ka BP (Figure 6a), where a significant increase in TOC from 0.2 to $0.8 \%$ is recorded (Figure 3). Tubinella funalis is sporadically reported in Antarctica, in environments from 100 to $550 \mathrm{~m}$ of depth [102], but unfortunately no direct ecological data are available for this species. On the contrary, in the Mediterranean Sea, it is indicative of upper slope-batial facies [103], as an infaunal taxon. In the studied core, it is likely indicative of a more productive sea bottom, as evidenced by the TOC content.

\subsubsection{Cibicides spp. FA}

This FA is consistent only from 12.8 to 8.7 and at approximately 15-16 ka BP (Figure 6a). In this interval, an evident decrease in carbonate content is recorded together with increasing sand content. Its distribution also coincides with the presence of IRD, particularly increased in Holocene sediments. Species of Cibicides, like C. lobatulus, C. antarcticus and, above all, C. refulgens, are indicative of strong bottom water currents $[27,79,101]$. Their occurrence suggests the beginning of oceanographic conditions, characterised by a strong current regime similar to those which are found today. Cape Adare is currently one of the preferred trajectories for large icebergs coming out of the Ross Sea, as observed recently by the authors of [53].

\subsection{Ostracod Associations (OAs) in the Carbonate Factory Environment}

The ostracods found in core ANTA91-9 allowed us to highlight the possible evolution in relation to the presence of four associations, as indicated by the analysis of the principal components. Using the ostracods, five OAs recognised by the PCA analysis explain the total variance of $78.4 \%$ (Table 3 ). In particular, it was possible to divide the core into different intervals characterised by the predominance of precise associations (OAs).

\subsubsection{Pseudocythere aff. P. Caudata OA}

In the intervals between 14.8-15.7 ka BP and 17.3-24 ka BP $(174-365 \mathrm{~cm})$ and sporadically in sediment older than $25.4 \mathrm{ka} \mathrm{BP}$, the prevalent OA consists of $P$. caudata together with A. devexa and Kangarina sp. (Figure 6a). They point to the possible influence of cold deep water in periantarctic areas (Magellan Strait) since the first two species could be related to the upwelling of cold deep water [89,92-94].

\subsubsection{Cytheropteron (Loxoreticulatum) Fallax OA}

This OA is abundant in the upper part of the core in the intervals 11.0-15.0 and 27.0-28.0 ka BP (Figure 6a). Cytheropteron fallax is signalled as characteristic of shallow depth often in association with phytal taxa or filter feeders, deposit feeders and predators/scavengers taxa [33,43,104]. Ayress et al. [94] recorded the presence of $C$. fallax in shallow depth characterised by Subantarctic Upper Water. The high values of $C$. fallax $\mathrm{OA}$ are also closely correlated with the increasing TOC and $\mathrm{C} / \mathrm{N}$ values as well as $\mathrm{CaCO}_{3}$ percentages (Figure 3). In particular, there is the significant increase in this factor in the levels between $11.0 \mathrm{ka}$ and $15.0 \mathrm{ka}$ followed by the concomitant decrease in P. caudata and B. simplex OAs, both indicative of changed paleoenvironmental and paleoclimatic conditions.

\subsubsection{Bairdoppilata Simplex OA}

The intervals from 17.8 to $18.6(184-212 \mathrm{~cm})$ and 21.6 to $29.3(314-477 \mathrm{~cm}) \mathrm{ka}$ BP are characterised by the $B$. simplex $\mathrm{OA}$ (Figure 6a). This species, together A. devexa, normally lives in deep water but could also be associated with upwelling of very cold water in the Magellan Strait area $[89,92,93]$. The associated species X. rigusa could also indicate the presence of the Antarctic Intermediate Waters current. 


\subsubsection{Australicythere Polylyca OA}

This association characterises the Holocene and sediments older than $26.0 \mathrm{ka}$ BP (Figure 6a). This eyed thaerocytherid species, common in Antarctic shallow waters (48-464 m) [33,89], was also found in the eastern Weddell Sea at $1030 \mathrm{~m}$ depth, possibly indicating its submergence from the Antarctic shelf [105]. This submergence could possibly be related to the extensive downslope water movement, which contributes to the formation of the bottom water masses worldwide [105].

Although statistically minor, the first appearance of several species belonging to the genus Polycope was highlighted in the studied core. They occur significantly during 14.8-15.2, 17.1-18.5, 20.9-22.8 and 25.7-27.6 ka BP (Figure 5). Polycope have been described in the Arctic Ocean [106,107], but they have never been reported in Antarctic sediment cores. Polycope are benthic species with the ability to swim rapidly over short distances [108,109]. However, their ecology is imperfectly understood because of their patchy distribution (geographically, ecologically and chronologically) and their delicate thin-shelled carapace. Although the authors of [110] reported the abundance of Polycope as indicative of organic-rich sediments and productivity in surface waters, this relationship was not observed in core ANTA91-9.

\subsection{Paleoenvironmental Reconstruction Inferred by the Microorganisms}

The integrated micropaleontological (foraminifer and ostracod) investigations together with the compositional, textural and geochemical data of this core provide new data for the paleoenvironmental and paleoceanographic reconstructions of the Cape Adare region over the last $30 \mathrm{ka} \mathrm{BP.} \mathrm{In} \mathrm{particular,}$ microfossils allow us to recognise four periods at ages $>21$, from 17.7 to 20.5 , approximately at 15.0 and finally from 10.6 to $12.7 \mathrm{ka} \mathrm{BP}$ in which the carbonate accumulation/production developed. During these periods, the Cape Adare area was not covered by ice shelves (Figure 6b), in agreement with [10] who demonstrated that carbonate factories operate during times of ice advance, when glacial expansion limited the influx of terrigenous sediments to the outer shelf.

In the sediments older $21 \mathrm{ka} \mathrm{BP,} \mathrm{coinciding} \mathrm{with} \mathrm{MIS2} \mathrm{and} \mathrm{the} \mathrm{LGM,} \mathrm{low} \mathrm{abundance} \mathrm{of} \mathrm{N.} \mathrm{pachyderma}$ and low TOC content likely suggest conditions of reduced productivity at the surface of the water column and likely the presence of sea ice, in agreement with [10]. During the LGM, winter and summer sea ice extension was twice the modern surface and was expanded northward of its modern position overlying the modern Antarctic Polar Front [111]. Even if N. pachyderma is perfectly adapted to live incorporated into the sea ice [112,113], its occurrence decreases from sea ice to pack ice and near the ice-shelf [114].

In the period before $22.0 \mathrm{ka}$, we find signs of upwelling, as represented by the B. simplex OA, and the possible intrusions of CDW, as represented by the E. exigua FA (Figure 6a). Epistominella exigua is considered an opportunistic species able to feed on fresh phytodetritus and adapted to fluctuating food supply in areas with sea ice occurrence $[85,96,97]$. However, considering the low TOC value of this period (Figure 6a), we believe that this small species indicates the occasional influence of the CDW. This interpretation fits well with the glacial model proposed by the authors of $[10,115]$. They indicated that during the LGM, the relatively unmodified CDW could flow south across the continental shelf since it is not contrasted by the HSSW, produced by wind-forced ice-front polynyas, which normally flows from inner to outer shelf. The ostracod association in sediments older than 21 ka shows high values of $P$. caudata, B. simplex and A. polylica OAs. In particular, in the levels $>26.0 \mathrm{ka}$, there is the concomitant increase with variable values of B. simplex and A. polylyca OAs. The simultaneous presence of high values of the genus Polycope supports the hypothesis of an environment characterised by occasional input of warmer and likely productive water (CDW), as testified by a light increase in TOC content (Figure 6a).

During the first evidence of glacial destabilisation, marked by a decrease in $\mathrm{CaCO}_{3}$ at approximately $21 \mathrm{ka} \mathrm{BP}$ (Figure 6b), the presence of weak and upwelling currents are highlighted by the M. subrotunda FA and P. caudata OA (Figure 6a). Even if the post LGM deglaciation is generally considered to start at around $18 \mathrm{ka} \mathrm{BP}$ in Antarctica [13], this period corresponds to a moderate $\delta^{18} \mathrm{O}$ decrease in the 
Taylor Dome record (Figure 3) [71]. At this time, a significant percentage increase in G. biora (Figure 4) is indicative of increased terrigenous supply as this taxon is indicative of increased sedimentation fluxes and sediment instability [18,30,62,99]. Similar evidences of a destabilisation of the Ross ice shelf-sea ice system were reported by the authors of [116] east of the Iselin Bank, from 17.2 to $28.2 \mathrm{ka}$ BP (as uncorrected ages). Bonaccorsi et al. [116] argued that these layers were deposited during a massive destabilisation caused by the meltwater pulse (MWP) at 19 ka.

The TOC content indicates an increase in primary productivity, from approximately 20.0 to $16.0 \mathrm{ka}$ BP. This leads to a slight increase in the concentration of N. pachyderma, but not that of the benthic foraminifers, which always show an oscillating trend (Figure 4). At least until 17.0 ka BP, the factors $P$. caudata and B. simplex OAs are of primary importance, suggesting a possible new ingression of productive water increasing trophic values. The $\mathrm{CaCO}_{3}$ content indicates a new carbonate factory period.

One further glacial terrigenous input which interrupts the carbonate factory at approximately 16.0-16.4 ka BP is evidenced by the G. biora FA and C. fallax OA (Figure 6a). This time agrees with [75], who stated that at 16.2-15.2 ka BP there is a small precursor of the main rapid ice loss which occurred during the MWP-1A. Furthermore, starting from about $16 \mathrm{ka}$ BP and more abundant toward the Holocene, the IRDs begin to be present in the gravel fraction, otherwise composed of calcareous remains, indicating major iceberg discharge [117].

A new carbonate factory expansion at 15-16 ka BP, with a strong decrease in TOC content, is again represented by E. exigua FA together with $P$. caudata and B. simplex OAs, likely indicating upwelling conditions (Figure 6a,b). The following event corresponds to the MWP-1A, at 14-15 ka BP, records a significant increase in TOC content together with a $\mathrm{CaCO}_{3}$ decrease and is represented by $T$. funalis FA and C. fallax OA. The foraminifer T. funalis is not particularly present in Antarctica, but seems to indicate increased accumulation of organic matter on the seafloor.

The last period of carbonate factory activity, at approximately $10.6-13.0 \mathrm{ka} \mathrm{BP}$, is still represented by $T$. funalis FA and C. fallax $\mathrm{OA}$ and corresponds to a slight $\delta^{18} \mathrm{O}$ increase in the Talos Dome ice record (Figure 6a). This time interval corresponds to the Antarctic Cold Reversal (ACR) when most temperature records in Antarctic ice cores show a different interruption of their warming [118,119]. This event was also recorded in the ANTA99-cJ5 sediment core by the authors of [120] with a marked reduction in the organic carbon content and by the authors of [74] in the Scotia Sea sector. According to the authors of [10], the ACR could conversely be witness to a recent recovery phase of carbonate factories in this Ross Sea area also underlined by increasing organic carbon content indicative of nutrient supply.

The last phase (from 11.0 to $8.0 \mathrm{ka} \mathrm{BP}$ ) leads to the new oceanographic trend at the bottom, with vigorous currents that winnow the bottom sediments. This period is represented by Cibicides FA and A. polylica OA. The recent sediment is not preserved (currents or loss during coring). The dominance of the A. polylyca OA, reinforced by a simultaneous drop in the ostracod associations (Figure 5), in this sense marks a dormant phase of the carbonate factory. The morphological characteristics of the dominant species A. polylyca, characterised by a wide and robust shell, could in fact indicate the final stage of the ice shelf retreat and the most pronounced ice-shelf melting from the Ross Ice Shelf [121].

\section{Conclusions}

Carbonates from polar areas and the marine organisms that compose them have significant potential for recording climate and oceanographic change in regions that are particularly sensitive to environmental and climate change on a global scale. In this sense, foraminifer and ostracod assemblages, analysed for the first time in a northwestern Ross Sea carbonate-rich deposit, made it possible to identify the late Quaternary (8.0-30.0 ka BP) oscillations (advance and retreat) of the ice shelf linked to the of activity and crisis episodes of the carbonate factories. Both groups showed similar responses to the palaeoenvironmental/climatic forcing, thus indicating the importance of the integrated use of the different microfossil proxies. 
Summarising, the analysis of the two taxa together with the compositional, textural and geochemical data has allowed the definition of precise intervals in which the carbonate factories were active or dormant:

1-Active carbonate factories during the intervals 10.6-12.7, 14.7-15.7, 17.7-20.5 ka BP and in the sediments older than $21.3 \mathrm{ka}$ BP in which prevail E. exigua, M. subrotunda and T. funalis FAs together with P. caudata and B. simplex OAs. High values of the genus Polycope support the hypothesis of an environment characterised by high productivity.

2-Inactive carbonate factories at 8.5-10.2, 13.5-14.7, 16.0-16.4, and approximately 20.5-21.1 ka BP characterised by the simultaneous dominance of Cibicides FA and A. polylyca OA.

Finally, these data will provide useful support for the interpretation of the complex climatic phases that have regulated the advances and retreats of the ice shelves. Furthermore, the recovery of this sedimentary series rich in calcareous organisms offers opportunities for future geochemistry studies in stable isotopes as well as $\mathrm{Mg} / \mathrm{Ca}$ and $\mathrm{Sr} / \mathrm{Ca}$ ratios for the detailed reconstruction of the paleotemperatures. These further analyses will allow us to refine the paleoclimatic analysis of this sector of the Ross Sea.

Supplementary Materials: The following are available online at http:/www.mdpi.com/2076-3263/10/10/413/s1, Figure S1: picture of core ANTA91-9. Section V and section I correspond to the top and bottom core, respectively. The unit of measures on the right is expressed in $\mathrm{cm}$. Table S1: semi quantitative analysis of the biogenic elements in the fraction of the sediment $>2 \mathrm{~mm} ; \mathbf{r}=$ rare (1-4 specimens/sample), $\mathbf{x}=$ frequent (5-19 specimens/sample), $\mathbf{x x}=$ very frequent (> 20 specimens/sample); Table S2: list of recognized foraminifer species, as number of specimens, recovered in ANTA91-09 core sediments. Shannon index $(\mathrm{H}), \%$ benthic and planktonic foraminifers and density ( $\mathrm{n}^{\circ}$ of specimens/g) have been added; Table S3: list of recognized ostracod species (\%) recovered in ANTA91-09 core sediments.

Author Contributions: Conceptualisation, methodology, investigation, R.M.; foraminifer analysis, R.M.; ostracod analysis, methodology, investigation G.S. Both authors contributed to the writing, review and editing of the original draft. All authors have read and agreed to the published version of the manuscript.

Funding: This research was financed by the Italian "Programma Nazionale di Ricerche in Antartide" (P.N.R.A.), Sedimentology and Seabed Sampling Project (leader F. Giorgetti) and the GRACEFUL Project (leader P. Montagna).

Acknowledgments: We are grateful to M. Bussi for the sedimentological analyses and C. Landucci for the TOC and $\mathrm{CaCO}_{3}$ analyses. Many thanks to $\mathrm{K}$. Close for the linguistic revision. We are grateful to the two anonymous reviewers who helped us to improve the writing.

Conflicts of Interest: The authors declare no conflict of interest. 


\section{Appendix A}

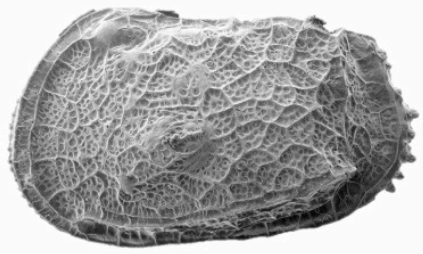

1 $\longrightarrow 100 \mu \mathrm{m}$
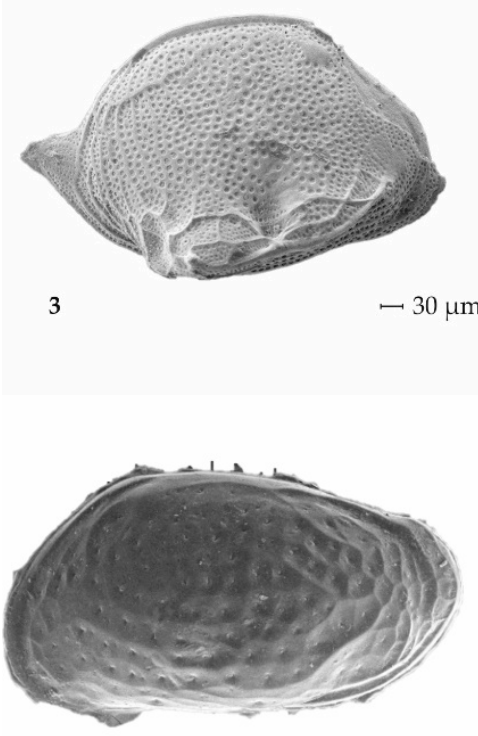

5

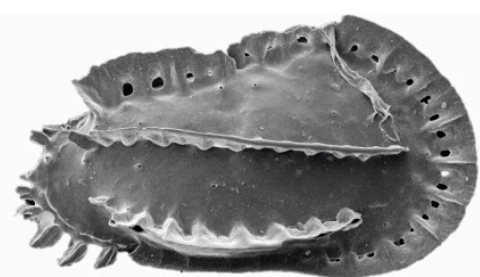

2

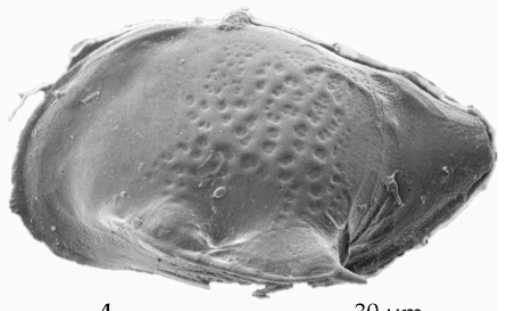

$-30 \mu \mathrm{m}$

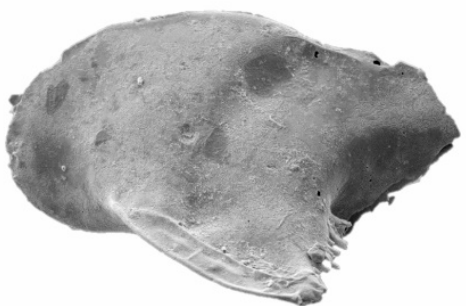

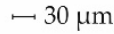

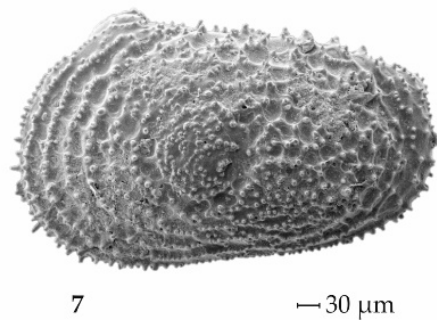

Figure A1. 1-Australicythere polylyca. Lateral exterior view, left valve; 2-Cativella bensoni. Lateral exterior view, right valve; 3-Cytheropteron abyssorum. Lateral exterior view, right valve; 4 -Cytheropteron antarcticum. Lateral exterior view, left valve; 5-Cytheropteron (Loxoreticulatum) fallax. Lateral exterior view, left valve; 6-Cytheropteron sp. Lateral exterior view, left valve; 7-Echinocythereis sp. Lateral exterior view, left valve. 

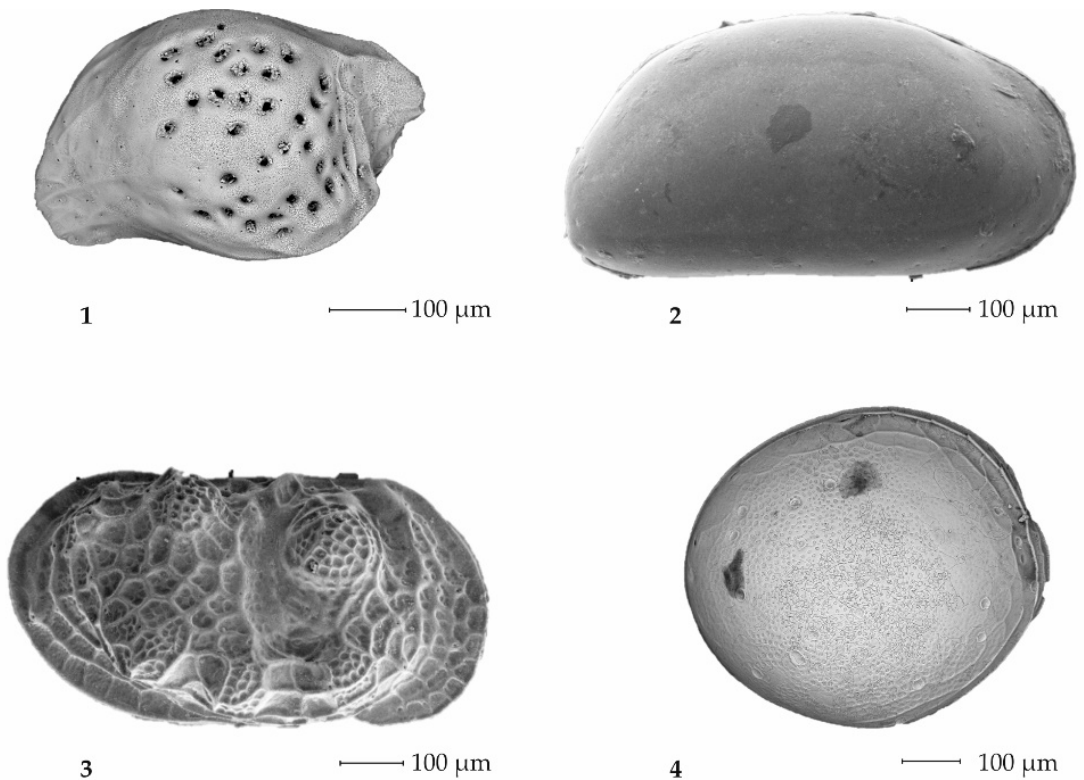

4 $100 \mu \mathrm{m}$
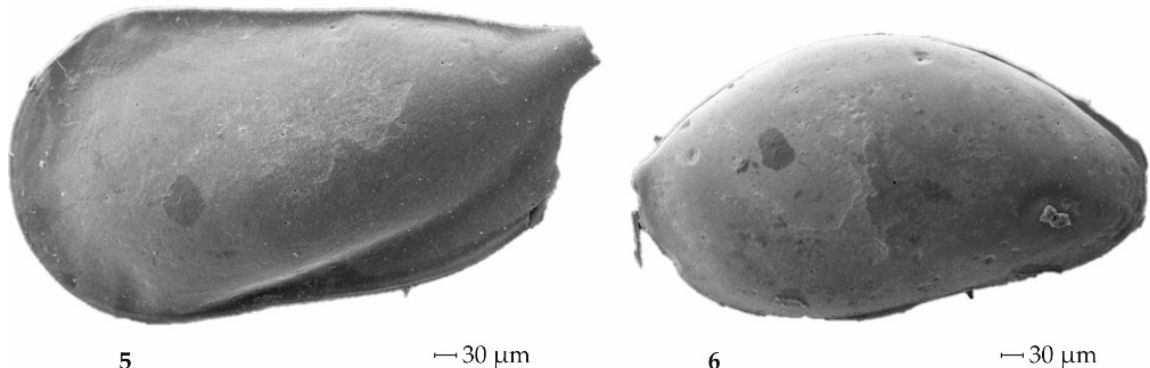

6 $\longmapsto 30 \mu \mathrm{m}$

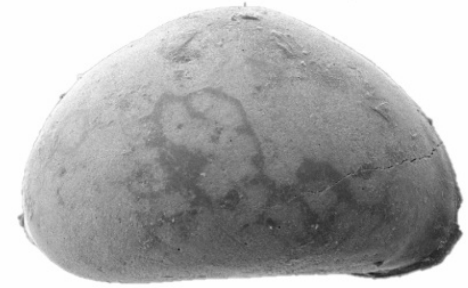

ط30 $\mu \mathrm{m}$

Figure A2. 1-Kangarina sp. Lateral exterior view, left valve; 2-Krithe (Austrokrithe) magna. Lateral exterior view, right valve; 3-Nodoconcha minuta. Lateral exterior view, right valve; 4-Polycope sp. Lateral exterior view, left valve; 5-Pseudocythere aff. P. caudata. Lateral exterior view, left valve; 6-Paradoxostoma hypselum. Lateral exterior view, right valve; 7-Xestoleberis rigusa. Lateral exterior view, right valve.

\section{References}

1. Kennett, J.P. Foraminiferal evidence of shallow calcium carbonate solution boundary, Ross Sea, Antarctica. Science 1966, 153, 191-193. [CrossRef] [PubMed]

2. Hauck, J.; Gerdes, D.; Hillenbrand, C.-D.; Hoppema, M.; Kuhn, G.; Nehrke, G.; Völker, C.; Wolf-Gladrow, D.A. Distribution and mineralogy of carbonate sediments on Antarctic shelves. J. Mar. Syst. 2012, 90, 77-87. [CrossRef]

3. Dejong, H.B.; Dunbar, R.B.; Mucciarone, D.; Koweek, D.A. Carbonate saturation state of surface waters in the Ross Sea and Southern Ocean: Controls and implications for the onset of aragonite undersaturation. Biogeosciences 2015, 12, 6881-6896. [CrossRef] 
4. Domack, E.W. Biogenic facies in the Antarctic glacimarine environment: Basis for a polar glacimarine summary. Palaeogeogr. Palaeoclim. Palaeoecol. 1988, 63, 357-372. [CrossRef]

5. Taviani, M.; Reid, D.E.; Anderson, J.B. Skeletal and isotopic composition and paleoclimatic significance of late Pleistocene carbonates, Ross Sea, Antarctica. J. Sedim. Petrol. 1993, 63, 84-90. [CrossRef]

6. Rao, C.P. Modern Carbonates: Tropical, Temperate and Polar-Introduction to Sedimentology and Geochemistry; Carbonates, Hobart: Tasmania, Australia, 1996; p. 206.

7. Taviani, M.; Claps, M. Biogenic Quaternary carbonates in the CRP-1 Drillhole, Victoria Land Basin, Antarctica. Terra Antartica 1998, 5, 411-418.

8. Brambati, A.; Fanzutti, G.P.; Finocchiaro, F.; Melis, R.; Pugliese, N.; Salvi, G.; Faranda, C. Some paleoecological remarks on the Ross Sea Shelf, Antarctica. In Ross Sea Ecology, Itali Antartide Expeditions (1987); Faranda, F., Guglielmo, E., Ianora, A., Eds.; Springer: Berlin/Heidelberg, Germany; New York, NY, USA, 1999; pp. 51-61.

9. Melis, R.; Colizza, E.; Pizzolato, F.; Rosso, A. Late Quaternary glacial marine sequences in Ross Sea (Antarctica): Paleoenvironmental inferences throughout calcareous taxa. Geobios 2002, 35, 207-218. [CrossRef]

10. Frank, T.D.; James, N.P.; Bone, Y.; Malcom, I.; Brenizer, L. Late Quaternary carbonate deposition at the bottom of the world. Sedim. Geol. 2014, 305, 1-16. [CrossRef]

11. Frank, T.D.; James, N.P.; Shultis, A.I. Lack of sinsedimentary chemical alteration in polar carbonates (Ross Sea, Antarctica): Resolution of a conundrum. J. Sedim. Res. 2020, 90, 449-467. [CrossRef]

12. Domack, E.W.; Taviani, M.; Rodriguez, A. Recent remoulding on a deep shelf, Ross Sea: Implications for radiocarbon dating of Antarctic marine sediments. Quat. Sci. Rev. 1999, 18, 1445-1451. [CrossRef]

13. Anderson, J.B.; Conway, H.; Bart, P.J.; Witus, A.E.; Greenwood, S.L.; McKay, R.M.; Hall, B.L.; Ackert, R.P.; Licht, K.; Jakobsson, M.; et al. Ross sea paleo-ice sheet drainage and deglacial history during and since the LGM. Quat. Sci. Rev. 2014, 100, 31-54. [CrossRef]

14. Halberstadt, A.R.W.; Simkins, L.M.; Greenwood, S.L.; Anderson, J.B. Past ice-sheet behaviour: Retreat scenarios and changing controls in the Ross Sea, Antarctica. Cryosphere 2016, 10, 1003-1020. [CrossRef]

15. James, N.P. The cool-water carbonate depositional realm. In Cool-Water Carbonates; James, N.P., Clarke, J.A.D., Eds.; SEPM Special Publication: Tulsa, OK, USA, 1997; Volume 56, pp. 1-20.

16. Webb, P.N.; Strong, C.P. Occurrence, stratigraphic distribution and palaeoecology. of quaternary foraminifera from CRP-1. Terra Antartica 1998, 5, 455-472.

17. Kidwell, S.M.; Fursich, F.T.; Aigner, T. Conceptual framework for the analysis and classification of fossil concentrations. Palaios 1986, 1, 228-238. [CrossRef]

18. Bart, P.J.; Coquereau, L.; Warny, S.; Majewski, W. In situ foraminifera in grounding zone diamict: A working hypothesis. Antarct. Sci. 2016, 28, 313-321. [CrossRef]

19. Majewski, W.; Prothro, L.O.; Simkins, L.M.; Demianiuk, E.J.; Anderson, J.B. Foraminiferal patterns in deglacial sediment in the Western Ross Sea, Antarctica: Life near grounding lines. Paleoceanogr. Paleoclim. 2020, 35, e2019PA003716. [CrossRef]

20. Majewski, W.; Anderson, J.B. Holocene foraminiferal assemblages from Firth of Tay, Antarctic Peninsula: Paleoclimate implications. Mar. Micropal. 2009, 73, 135-147. [CrossRef]

21. Jacobs, S.S.; Giulivi, C.F. Thermohaline data and ocean circulation on the Ross Sea continental shelf. In Oceanography of the Ross Sea, Antarctica; Spezie, G., Manzella, G., Eds.; Springer: Milano, Italy, 1999; pp. 3-16.

22. Bergamasco, A.; Defendi, V.; Budillon, G.; Spezie, G. Downslope flow observations near Cape Adare shelf-break. Antarct. Sci. 2004, 16, 199-204. [CrossRef]

23. Gordon, A.L.; Zambianchi, E.; Orsi, A.; Visbeck, M.; Giulivi, C.F.; Whitworth, T., III; Spezie, G. Energetic plumes over the western Ross Sea continental slope. Geoph. Res. Lett. 2004, 31, L21302. [CrossRef]

24. Gordon, A.L.; Orsi, A.H.; Muench, R.; Huber, B.A.; Zambianchi, E.; Visbeck, M. Western Ross Sea continental slope gravity currents. Deep Sea Res. II 2009, 56, 796-817. [CrossRef]

25. Muench, R.D.; Wåhlin, A.K.; Özgökmen, T.M.; Hallberg, R.; Padman, L. Impacts of bottom corrugations on a dense Antarctic outflow: NW Ross Sea. Geophys. Res. Lett. 2009, 36, L23607. [CrossRef]

26. Davey, F.J. (Ed.) Ross Sea Bathymetry 1:2,000,000, Version 1.0; Institute of Geological \& Nuclear Sciences Limited: Lower Hutt, New Zealand, 2004.

27. Violanti, D. Taxonomy and distribution of recent benthic foraminifers from Terra Nova Bay (Ross Sea, Antarctica), Oceanographic Campaign 1987/1988. Palaeontogr. Ital. 1996, 83, 25-71.

28. Murray, J.W.; Pusdey, C.J. Living (stained) and dead foraminifera from the newly ice-free Larsen Ice Shelf, Weddell Sea, Antarctica: Ecology and taphonomy. Mar. Micropaleontol. 2004, 53, 67-81. [CrossRef] 
29. Majewski, W. Benthic foraminiferal distribution and ecology in Admiralty Bay, King George Island, West Antarctica. Pol. Polar Res. 2005, 26, 159-214.

30. Majewski, W.; Bart, P.J.; McGlannan, A.J. Foraminiferal assemblages from ice-proximal paleo-settings in the Whales Deep Basin, Eastern Ross Sea, Antarctica. Palaeogeogr. Palaeoclim. Palaeoecol. 2018, 493, 64-81. [CrossRef]

31. Ellis and Messina Catalogues. Available online: http://www.micropress.org (accessed on 30 June 2020).

32. Hammer, O.; Harper, D.A.T.; Ryan, P.D. PAST: Paleonto-logical statistics software package for education and data analysis. Palaeontol. Electron. 2001, 4, 1-9.

33. Yasuhara, M.; Kato, M.; Ikeya, N.; Seto, K. Modern benthic ostracodes from Lützow-Holm Bay, East Antarctica: Paleoceanographic, paleobiogeographic, and evolutionary significance. Micropaleontology 2007, 53, 469-496. [CrossRef]

34. Brandão, S.N.; Horne, D.V. The platycopid signal of oxygen depletion in the ocean: A critical evaluation of the evidence from modern ostracod biology, ecology and depth distribution. Palaeogeogr. Palaeoclim. Palaeoecol. 2009, 283, 126-133. [CrossRef]

35. Benson, R.H. Recent Cytheracean Ostracodes from McMurdo Sound and the Ross Sea, Antarctica. Arthropoda 1964, 6, 1-36.

36. Neale, J.W. An Ostracod Fauna Halley Bay, Coast Land, British Antarctic Territory; British Antarctic Survey: Cambridge, UK, 1967; Volume 68, pp. 1-50.

37. Hartmann, G. Antarktische benthische Ostracoden IX. Ostracoden von der Antarktischen Halbinsel und von der Isla de los Estados (Feuerland/Argentinien). Auswertung der "Polarstern" Reise PS ANT/X/1b. Mitteilungen aus dem Hamburgischen zoologischen Museum und Institut 1993, 90, 227-237.

38. Hartmann, G. Antarktische benthische Ostracoden X. Bemerkungen zur Gattung Krithe mit Beschreibung einer neuen Untergattung Austrokrithe. Mitteilungen aus dem Hamburgischen zoologischen Museum und Institut 1994, 91, 77-79.

39. Hartmann, G. Antarktische und Subantarktische Podocopa (Ostracoda). In Synopses of the Antarctic Benthos; Wagele, J.W., Sieg, J., Eds.; Koeltz Scientific Books, Koenigstein: Oberreifenberg, Germany, 1997; Volume 7, pp. 1-355.

40. Whatley, R.C.; Moguilevsky, A.; Ramos, M.I.F.; Coxill, D.J. Recent deep and shallow water Ostracoda from the Antarctic Peninsula and the Scotia Sea. Rev. Esp. Micropal. 1998, 30, 111-135.

41. Dingle, R.V. Insular endemism in recent Southern Ocean benthic Ostracoda from Marion Island: Palaeozoogeographical and evolutionary implications. Rev. Esp. Micropal. 2002, 34, 215-233.

42. Dingle, R.V. Recent subantarctic benthic ostracod faunas from the Marion and Prince Edward Islands archipelago, Southern Ocean. Rev. Esp. Micropal. 2003, 35, 119-155.

43. Majewski, W.; Olempska, E. Recent ostracods from Admiralty Bay, King George Island, West Antarctica. Pol. Polar Res. 2005, 26, 13-36. [CrossRef]

44. Hedges, J.I.; Stern, J.H. Carbon and nitrogen determinations of carbonate-containing solids. Limnol. Oceanogr. 1984, 29, 657-663. [CrossRef]

45. Hillenbrand, C.D.; Smith, J.; Hodell, D.A.; Greaves, M.; Poole, C.R.; Kender, S.; Williams, M.; Andersen, T.J.; Jernas, P.E.; Elderfield, H.; et al. West Antarctic Ice Sheet retreat driven by Holocene warm water incursions. Nature 2017, 547, 43-48. [CrossRef]

46. Reimer, P.J.; Bard, E.; Bayliss, A.; Beck, J.W.; Blackwell, P.G.; Bronk Ramsey, C.; Buck, C.E.; Edwards, R.L.; Friedrich, M.; Grootes, P.M.; et al. IntCal13 and Marine13 radiocarbon age calibration curves, 0-50,000 years cal BP. Radiocarbon 2013, 55, 1869-1887. [CrossRef]

47. Blaauw, M. Methods and code for 'classical' age-modelling of radiocarbon sequences. Quat. Geochr. 2010, 5, 512-518. [CrossRef]

48. Malmgren, B.A.; Haq, B.U. Assessment of quantitative techniques in paleobiogeography. Mar. Micropal. 1982, 7, 213-236. [CrossRef]

49. Majewski, W.; Wellner, J.S.; Anderson, J.B. Environmental connotations of benthic foraminiferal assemblages from coastal West Antarctica. Mar. Micropal. 2016, 124, 1-15. [CrossRef]

50. Licht, K.J.; Andrews, J.T. The $14 \mathrm{C}$ record of Late Pleistocene ice advance and retreat in the central Ross Sea, Antarctica. Arct. Antarct. Alp. Res. 2002, 34, 324-333. [CrossRef]

51. Mosola, A.B.; Anderson, J.B. Expansion and rapid retreat of the West Antarctic Ice Sheet in eastern Ross Sea: Possible consequence of over-extended ice streams? Quat. Sci. Rev. 2006, 25, 2177-2196. [CrossRef] 
52. Prothro, L.O.; Majewski, W.; Yokoyama, Y.; Simkins, L.M.; Anderson, J.B.; Yamane, M.; Miyairi, Y.; Ohkouchi, N. Timing and pathways of East Antarctic Ice Sheet retreat. Quat. Sci. Rev. 2020, 230, 106166. [CrossRef]

53. Martin, S.; Drucker, R.; Aster, R.; Davey, F.; Okal, E.; Scambos, T.; MacAyeal, D. Kinematic and seismic analysis of giant tabular iceberg breakup at Cape Adare, Antarctica. J. Geophys. Res. 2010, 115, B06311. [CrossRef]

54. Clark, P.U.; Dyke, A.S.; Shakun, J.D.; Carlson, A.E.; Clark, J.; Wohlfarth, B.; Mitrovica, J.X.; Hostetler, S.W.; McCabe, A.M. The Last Glacial Maximum. Science 2009, 325, 710-714. [CrossRef]

55. Bullivant, J.S. Ecology of the Ross Sea benthos. In The Fauna of the Ross Sea, Part 5. General Accounts, Station Lists and Benthic Ecology; Bullivant, J.S., Deaborn, J.H., Eds.; New Zealand Department of Scientific and Industrial Research Bulletin: Washington, DC, USA, 1967; Volume 176, pp. 49-77.

56. Nota, D.J.G. Sediments of the Western Guiana Shelf. Ph.D. Thesis, Mededel, Landbouwhogaschool, Wageningen, The Netherlands, 1958.

57. Boreen, T.D.; James, N.P. Holocene sediment dynamics on cool-water carbonate shelf: Otway, Southeaster Australia. J. Sedim. Petrol. 1993, 63, 574-588. [CrossRef]

58. Passlow, V. Slope sedimentation and shelf to basin sediment transfer: A cool-water carbonate example from the Otway Margin, Southeastern Australia. In Cool-Water Carbonates; James, N.P., Clarke, A.D., Eds.; SEPM Special Publication: Tulsa, OK, USA, 1997; Volume 56, pp. 107-125.

59. Bé, A.W.H. Some observations on arctic planktonic Foraminifera. Contr. Cush. Found. Foram. Res. 1960, 11, 64.

60. Kohfeld, K.E.; Fairbanks, R.G.; Smith, S.L.; Walsh, I.D. Neogloboquadrina pachyderma sinistral coiling as paleoceanographic tracers in polar oceans: Evidence from Northeast Water Polynya plankton tow, sediment traps, and surface sediments. Paleoceanography 1996, 11, 679. [CrossRef]

61. Greenwood, S.L.; Simkins, L.M.; Halberstadt, A.R.W.; Prothro, L.O.; Anderson, J.B. Holocene reconfiguration and readvance of the East Antarctic Ice Sheet. Nat. Commun. 2018, 9, 3176. [CrossRef]

62. Prothro, L.O.; Simkins, L.M.; Majewski, W.; Anderson, J.B. Glacial retreat patterns and processes determined from integrated sedimentology and geomorphology records. Mar. Geol. 2018, 395, 104-119. [CrossRef]

63. Anderson, J.B.; Brake, C.F.; Myers, N.C. Sedimentation on the Ross Sea continental shelf, Antarctica. Mar. Geol. 2018, 57, 295-333. [CrossRef]

64. Simkins, L.M.; Anderson, J.B.; Greenwood, S.L.; Gonnermann, H.M.; Prothro, L.O.; Halberstadt, A.R.W.; Stearns, L.A.; Pollard, D.; DeConto, R.M. Anatomy of a meltwater drainage system beneath the ancestral East Antarctic ice sheet. Nat. Geosci. 2017, 10, 691-697. [CrossRef]

65. Yokoyama, Y.; Purcell, A.; Ishiwa, T. Gauging quaternary sea level changes through scientific ocean drilling. Oceanography 2019, 32, 64-71. [CrossRef]

66. Licht, K.J.; Dunbar, N.W.; Andrews, J.T.; Jennings, A.E. Distinguishing subglacial till and glacial marine diamictons in the western Ross Sea, Antarctica: Implications for a last glacial maximum grounding line. Geol. Soc. Am. Bull. 1999, 111, 91-103. [CrossRef]

67. Cairns, S.D. Global Diversity of the Stylasteridae (Cnidaria: Hydrozoa: Athecatae). PLoS ONE 2011, 6, e21670. [CrossRef]

68. King, T.M.; Rosenheim, B.E.; Post, A.L.; Gabris, T.; Burt, T.; Domack, E.W. Large-scale intrusion of Circumpolar Deep Water on Antarctic margin recorded by stylasterid corals. Paleoceanogr. Paleoclim. 2018, 33, 1306-1321. [CrossRef]

69. Smith, W.O., Jr.; Marra, J.; Hiscock, M.R.; Barber, R.T. The seasonal cycle of phytoplankton biomass and primary productivity in the Ross Sea, Antarctica. Deep Sea Res. Part II 2000, 47, 119-140. [CrossRef]

70. Jouzel, J.; Masson, V.; Cattani, O.; Falourd, S.; Stievenard, M.; Stenni, B.; Longinelli, A.; Johnsen, S.J.; Steffenssen, J.P.; Petit, J.R.; et al. A new 27 ky high resolution East Antarctic climate record. Geoph. Res. Lett. 2001, 28, 3199-3202. [CrossRef]

71. Grootes, P.M.; Steig, E.J.; Stuiver, M. The oxygen isotope record from Taylor Dome, Antarctica. EOS Trans. 1994, 76, S176. [CrossRef]

72. Fairbanks, R.A. 17,000-year glacio-eustatic sea level record: Influence of glacial melting rates on the Younger Dryas event and deep-ocean circulation. Nature 1989, 342, 637-642. [CrossRef]

73. EPICA members. One-to-one coupling of glacial climate variability in Greenland and Antarctica. Nature 2006, 444, 195-198. 
74. Xiao, W.; Esper, O.; Gersonde, R. Last Glacial-Holocene climate variability in the Atlantic sector of the Southern Ocean. Quat. Sci. Rev. 2016, 135, 115-137. [CrossRef]

75. Golledge, N.R.; Menviel, L.; Carter, L.; Fogwill, C.J.; England, M.H.; Levy, R.H. Antarctic contribution to meltwater pulse 1A from reduced Southern Ocean overturning. Nat. Commun. 2014, 5, 5107. [CrossRef]

76. Lowry, D.P.; Golledge, N.R.; Bertler, N.A.N.; Jones, R.S.; McKay, R. Deglacial grounding-line retreat in the Ross Embayment, Antarctica, controlled by ocean and atmosphere forcing. Sci. Adv. 2019, 5, eaav8754. [CrossRef] [PubMed]

77. Osterman, L.E.; Kellogg, T.B. Recent benthic foraminiferal distributions from the Ross Sea, Antarctica: Relation to ecologic and oceanographic conditions. J. For. Res. 1979, 9, 250-269. [CrossRef]

78. Milam, R.W.; Anderson, J.B. Distribution and ecology of recent benthonic foraminifera of the Adelie-George V continental shelf and slope, Antarctica. Mar. Micropal. 1981, 6, 297-325. [CrossRef]

79. Mackensen, A.; Grobe, H.; Kuhn, G.; Fütterer, D.K. Benthic foraminiferal assemblages from the eastern Weddell Sea between $68^{\circ}$ and $73^{\circ}$ S: Distribution, ecology and fossilization potential. Mar. Micropal. 1990, 16, 241-283. [CrossRef]

80. Ishman, S.E.; Domack, E.W. Oceanographic controls on benthic foraminifers from the Bellingshausen margin of the Antarctic Peninsula. Mar. Micropal. 1994, 24, 119-155. [CrossRef]

81. Mikhalevich, V.I. The general aspects of the distribution of Antarctic foraminifera. Micropaleontology 2004, 50, 179-194. [CrossRef]

82. Rodrigues, A.R.; Cattini Maluf, J.C.; De Santis Braga, E.; Eichler, B.B. Recent benthic foraminiferal distribution and related environmental factors in Ezcurra Inlet, King George Island, Antarctica. Antarct. Sci. 2010, 22, 343-360. [CrossRef]

83. Capotondi, L.; Bergami, C.; Giglio, F.; Langone, L.; Ravaioli, M. Benthic foraminifera distribution in the Ross Sea (Antarctica) and its relationship to oceanography. Boll. Della Soc. Paleontol. Ital. 2018, 57, 187-202. [CrossRef]

84. McGlannan, A.J.; Bart, P.J.; Chow, J.M.; DeCesare, M. On the influence of post-LGM ice shelf loss and grounding zone sedimentation on West Antarctic ice sheet stability. Mar. Geol. 2017, 392, 151-169. [CrossRef]

85. Wollenburg, J.E.; Mackenesen, A. Living benthic foraminifers from the central Arctic Ocean: Faunal composition, standing stock and diversity. Mar. Micropal. 1998, 34, 153-185. [CrossRef]

86. Murray, J.W. Ecology and Applications of Benthic Foraminifera; Cambridge University Press: New York, NY, USA, 2006; p. 426.

87. Capotondi, L.; Bonomo, S.; Budillon, G.; Giordano, P.; Langone, L. Living and dead benthic foraminiferal distribution in two areas of the Ross Sea (Antarctica). Rendiconti Lincei. Scienze Fisiche e Naturali 2020, 1-17. [CrossRef]

88. Cai, H.M. Holocene Ostracoda and sedimentary environment implication in the core NG931-1 from the Great Wall Bay, Antarctica. Antarct. Res. 1996, 7, 141-149.

89. Dingle, R.V. Ostracoda from CRP-1 and CRP-2/2A, Victoria Land Basin, Antarctica. Terra Antarctica 2000, 7, 479-492.

90. Rathburn, A.E.; Pichon, J.J.; Ayress, M.A.; De Deckker, P. Microfossil and stable-isotope evidence for changes in Late Holocene palaeoproductivity and palaeoceanographic conditions in the Prydz Bay region of Antarctica. Palaeogeogr. Palaeoclim. Palaeoecol. 1997, 131, 485-510. [CrossRef]

91. Whatley, R.C.; Roberts, R. Late Quaternary Ostracoda from a core in the Weddell Sea, Antarctica. Pesquisas em Geociências 1999, 26, 11-19. [CrossRef]

92. Whatley, R.C.; Staunton, M.; Kaesler, R.L.; Moguilevsky, A. The taxonomy of Recent Ostracoda from the southern part of the Strait of Magellan. Revista Española de Micropaleontología 1996, 28, 51-76.

93. Whatley, R.C.; Staunton, M.; Kaesler, R.L. The depth distribution of recent marine Ostracoda from the southern Strait of Magellan. J. Micropal. 1997, 16, 121-130. [CrossRef]

94. Ayress, M.A.; De Deckker, P.; Coles, G.P. A taxonomic and distributional survey of marine benthonic Ostracoda off Kerguelen and Heard Islands, South Indian Ocean. J. Micropal. 2004, 23, 15-38. [CrossRef]

95. Mackensen, A.; Fütterer, D.K.; Groge, H.; Schmield, G. Benthic foraminiferal assemblages from the eastern South Atlantic Polar Front region between $35^{\circ}$ and $57^{\circ} \mathrm{S}$ : Distribution, ecology and fossilization potential. Mar. Micropal. 1993, 22, 33-69. [CrossRef]

96. Gooday, A.J. Deep sea benthic foraminiferal species which exploit phytodetritus: Characteristic features and controls on distribution. Mar. Micropal. 1993, 22, 187-205. [CrossRef] 
97. Schmiedl, G.; Mackensen, A.; Muller, P.J. Recent benthic foraminifera from eastern South Atlantic Ocean: Dependence on food supply and water masses. Mar. Micropal. 1997, 32, 249-287. [CrossRef]

98. Echols, R.J. Distribution of Foraminifera in Sediments of the Scotia Sea Area, Antarctic Waters; Reid, J.L., Ed.; Antarctic Oceanology I, Antarctic Research Series; American Geophysical Union: Washington, DC, USA, 1971; Volume 15, pp. 93-168.

99. Melis, R.; Salvi, G. Late Quaternary foraminiferal assemblages from western Ross Sea (Antarctica) in relation to the main glacial and marine lithofacies. Mar. Micropal. 2009, 70, 39-53. [CrossRef]

100. Majewski, W.; Pawlowski, J. Morphologic and molecular diversity of the foraminiferal genus globocassidulina in Admiralty Bay, West Antarctica. Antarct. Sci. 2010, 22, 271-281. [CrossRef]

101. Ishman, S.E.; Szymcek, P. Foraminiferal distributions in the former Laresen-A ice shelf and Prince Gustav channel region, eastern Antarctic Peninsula margin: A baseline for Holocene paleoenvironmental change. Antar. Res. Ser. 2003, 79, 239-260. [CrossRef]

102. Kennett, J.P. The Fauna of the Ross Sea: Part 6: Ecology and Distribution of Foraminifera; New Zealand Oceanographic Institute: Auckland, New Zealand, 1968; Volume 186, pp. 1-47.

103. Berggren, W.W.; Miller, K.G. Cenozoic bathyal and abyssal calcareous benthic foraminiferal zonation. Micropaleontology 1989, 35, 308-320. [CrossRef]

104. Sicinski, J.; Jazdzewski, K.; De Broyer, C.; Presier, P.; Ligowski, R.; Nonato, E.F.; Corbisier, T.N.; Petti, M.A.V.; Brito, T.A.S.; Lavrado, H.P.; et al. Admiralty bay benthos diversity-A census of a complex polar ecosystem. Deep Sea Res. II 2011, 58, 30-48. [CrossRef]

105. Brandt, A.; Gooday, A.J.; Brandaõ, S.N.; Brix, S.; Brökeland, W.; Cedhagen, T.; Choudhury, M.; Cornelius, N.; Danis, B.; De Mesel, I.; et al. First insights into the biodiversity and biogeography of the Southern Ocean deep sea. Nature 2007, 447, 307-311. [CrossRef] [PubMed]

106. Cronin, T.M.; Holtz, T.R., Jr.; Stein, R.; Spielhagen, R.; Fütterer, D.; Wollenberg, J. Late quaternary paleoceanography of the Eurasian Basin, Arctic Ocean. Paleoceanography 1995, 10, 259-281. [CrossRef]

107. Gemery, L.; Cronin, T.M.; Poirier, R.K.; Pearce, C.; Barrientos, N.; O’Regan, M.; Johansson, C.; Koshurnikov, A.; Jakobsson, M. Central Arctic Ocean paleoceanography from $50 \mathrm{ka}$ to present, on the basis of ostracode faunal assemblages from the SWERUS 2014 expedition. Clim. Past 2017, 13, 1473-1489. [CrossRef]

108. Kornicker, L.S. Distribution of the ostracod suborder Cladopoda, a new species from the Bahamas. Micropaleontology 1959, 5, 69-75. [CrossRef]

109. Neale, J.W. Geological history of the Cladocopina. In Applications on Ostracoda, Proceedings of the Eighth International Symposium on Ostracoda, Houston, TX, USA, 26-29 July 1982; Maddocks, R.F., Ed.; Department of Geosciences, University of Oslo: Oslo, Norway, 1983; pp. 612-626.

110. Cronin, T.M.; Holtz, T.R.; Whatley, R.C. Quaternary paleoceanography of the deep Arctic Ocean based on quantitative analysis of Ostracoda. Mar. Geol. 1994, 119, 305-332. [CrossRef]

111. Gersonde, R.; Zielinski, U. The reconstruction of late Quaternary Antarctic sea-ice distribution-The use of diatoms as a proxy for sea ice. Palaeogeogr. Palaeoclimatol. Palaeoecol. 2000, 162, 263-286. [CrossRef]

112. Hendry, K.R.; Rickaby, R.E.; Meredith, M.P.; Elderfield, H. Controls on stable isotope and trace metal uptake in Neogloboquadrina pachyderma (sinistral) from an Antarctic sea-ice environment. Earth Planet Sci. Lett. 2009, 278, 67-77. [CrossRef]

113. Mikis, A.; Hendry, K.R.; Pike, J.; Schmidt, D.N.; Edgar, K.M.; Peck, V.; Peeters, F.J.C.; Leng, M.J.; Meredith, M.P.; Todd, C.L.; et al. Temporal variability in foraminiferal morphology and geochemistry at the West Antarctic Peninsula: A sediment trap study. Biogeosciences 2019, 16, 3267-3282. [CrossRef]

114. Dieckmann, G.S.; Spindler, M.; Lange, M.A.; Ackley, S.F.; Eicken, H. Antarctic sea ice: A habitat for the foraminifer Neogloboquadrina pachyderma. J. Foram. Res. 1991, 21, 182-189. [CrossRef]

115. Tinto, K.J.; Padman, L.; Siddoway, C.S.; Springer, S.R.; Fricker, H.A.; Das, I.; Tontini, F.C.; Porter, D.F.; Frearson, N.P.; Howard, S.L.; et al. Ross Ice Shelf response to climate driven by the tectonic imprint on seafloor bathymetry. Nat. Geosci. 2019, 12, 441-449. [CrossRef]

116. Bonaccorsi, R.; Quaia, T.; Burckle, L.H.; Anderson, R.F.; Melis, R.; Brambati, A. C-14 age control of pre- and post-LGM events using N. pachyderma preserved in deep-sea sediments (Ross Sea, Antarctica). In Antarctica: A Keystone in a Changing World; Cooper, A.K., Raymond, C.R., Eds.; Department of Geological, Environmental, and Marine Sciences, University of Trieste: Trieste, Italy, 2007; p. 4, USGS Open-File Report 2007-1047, Extended Abstract 098. [CrossRef] 
117. Weber, M.E.; Clark, P.U.; Kuhn, G.; Timmermann, A.; Sprenk, D.; Gladstone, R.; Zhang, X.; Lohmann, G.; Menviel, L.; Chikamoto, M.O.; et al. Millennial-scale variability in Antarctic ice-sheet discharge during the last. Nature 2014, 510, 134-138. [CrossRef] [PubMed]

118. Stenni, B.; Masson, V.; Johnsen, S.J.; Jouzel, J.; Longinelli, A.; Monnin, E.; Selmo, E. An oceanic cold reversal during the last deglaciation. Science 2001, 293, 2074-2077. [CrossRef]

119. Pedro, J.B.; Bostock, H.C.; Bitz, C.M.; He, F.; Vandergoes, M.J.; Steig, E.J.; Chase, B.M.; Krause, C.E.; Rasmussen, S.O.; Markle, B.R.; et al. The spatial extent and dynamics of the Antarctic Cold Reversal. Nat. Geosci. 2015, 9, 51-55. [CrossRef]

120. Salvi, C.; Salvi, G.; Stenni, B.; Brambati, A. Palaeoproductivity in the Ross Sea, Antarctica, during the last 15 kyr B.P. and its link with ice-core temperature proxies. Ann. Glaciol. 2004, 39, 445-451. [CrossRef]

121. Yokoyama, Y.; Anderson, J.B.; Yamane, Y.; Simkins, L.M.; Miyairi, Y.; Yamazaki, T.; Koizumi, M.; Suga, H.; Kusahara, K.; Prothro, L.; et al. Widespread collapse of the Ross Ice Shelf during the late Holocene. Proc. Natl. Acad. Sci. USA 2016, 113, 2354-2359. [CrossRef]

Publisher's Note: MDPI stays neutral with regard to jurisdictional claims in published maps and institutional affiliations.

(C) 2020 by the authors. Licensee MDPI, Basel, Switzerland. This article is an open access article distributed under the terms and conditions of the Creative Commons Attribution (CC BY) license (http://creativecommons.org/licenses/by/4.0/). 